\title{
The Effects of Penta-Brominated Diphenyl Ether (penta-BDE, BDE-99) on Human Embryonic Kidney (HEK293) Cells
}

\author{
By \\ Mary Daniel \\ A thesis submitted to the Faculty of Graduate and Postdoctoral Affairs in partial \\ fulfillment of the requirements for the degree of \\ Master of Science \\ In \\ Biology: Specialization in Chemical and Environmental Toxicology \\ Carleton University \\ Ottawa, Ontario \\ (C) 2016 \\ Mary Daniel
}




\begin{abstract}
Individuals are exposed to toxic chemicals on a daily basis. Some toxic chemicals produce reactive oxygen species (ROS), which contribute to protein modification and the accumulation of protein carbonyl groups. The antioxidant response to ROS involves the binding of nuclear factor-erythroid 2 subunit-related transcription factors (NFE2L or Nrfs) to antioxidant response elements (AREs)/electrophile response elements (EpREs), located in the promoter and enhancer regions of antioxidant and detoxification enzymes.

Activation of the AREs/EpREs pathway by Nrf proteins, in response to pentabrominated diphenyl ether (penta-BDE, BDE-99) flame retardant, was observed. Protein damage (as assessed protein carbonyl assays), lipid damage (as assessed by oxidation assays), and the activation of the beta-galactosidase enzyme occurred as a results of penta-BDE treatment. These results provide insight into how penta-BDE a) initiates the antioxidant response, b) damages proteins and lipids through ROS and c) increases betagalactosidase activity.
\end{abstract}




\section{Acknowledgements}

I would like to thank my family for their continued support and motivation throughout my academic career. I would also like to thank Dr. Willmore and the Willmore Lab for direction, assistance, and lots of great memories. I would also like to thank Dr. Robert Letcher from the National Wildlife Research Centre, for providing us with the penta-brominated diphenyl ether chemical, and for guidance in how to prepare it and use it. I would also like to thank NSERC Discovery and CREATE Grants to Dr. Willmore for providing the funding needed to conduct this study. 


\section{Table of Contents}

Abstract..................................................................................ii

Acknowledgements....................................................................ii

Table of Contents.................................................................

List of Tables............................................................................vii

List of Figures................................................................viii

List of Abbreviations.................................................................x

Chapter 1: Introduction............................................................1

1.1: Oxidative Stress, ROS, Free Radicals.................................

1.2: Antioxidant Response Element....................................4

1.3: Nuclear Factor-Erythroid 2 Subunit-Related-1 (Nrf1)....................5

1.4: Cellular Senescence...............................................

1.5: Polybrominated Diphenyl Ethers................................ 10

1.6: Toxicological Background of PBDEs................................13

1.7: Current Concern and Regulations on PBDEs.......................... 16

1.8: Cell Lines Used.................................................17

1.9: Hypothesis and Objectives......................................17

Chapter 2: Materials and Methods................................................21

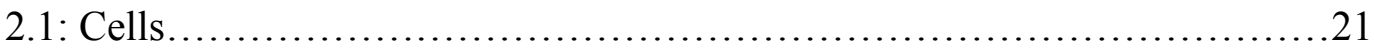

2.2: Chemicals and Reagents.......................................21

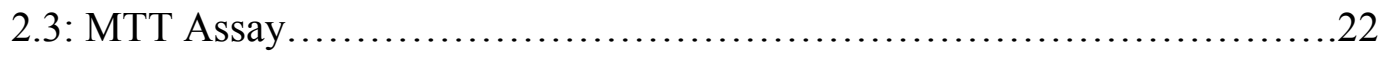

2.4: Western Blotting..............................................22 
2.5: Protein Carbonyl Assay..........................................23

2.6: 8-Isoprostanes Assay.................................................24

2.7: Luciferase Reporter Assay.......................................24

2.8: Flow Cytometry for measuring Senescence Associated Beta-Galactosidase

Activity...................................................26

2.9: Statistical Analysis...............................................27

Chapter 3: Results..............................................................28

3.1: Determination of Chemical Concentrations............................28

3.2: Increased Chemical Treatment Results in Increased Nrf Protein

Expression.................................................28

3.3: Increased Chemical Treatment Results in Increased Levels of Protein

Carbonyl Groups............................................. 35

3.4: Increased Chemical Treatment Results in Increased Levels of 8-

Isoprostane.................................................. 35

3.5: Increased Chemical Treatment Results in Increased Nrf Transactivation

Activity....................................................40

3.6: Increased Chemical Treatment Results in Increased Levels of Beta-

Galactosidase Activity Using Flow Cytometry......................40

Chapter 4: Discussion.................................................................46

4.1: Hydrogen Peroxide Is A Strong Pro-oxidant That Increases Nrf1 And Nrf2

Protein Levels...................................................46

4.2: Penta-Brominated Diphenyl Ether Treatment Increases Nrf1 and Nrf2 Protein

Levels.......................................................46 
4.3: Protein Carbonyl Group Production and Aging.

4.4: Lipid Oxidation and Aging..........................................49

4.5: Activation of the ARE/ EpRE by Penta-BDE.........................50

4.6: Senescence-Associated Beta-Galactosidase (SA- $\beta$-Gal) Activity Increases

with $\mathrm{H}_{2} \mathrm{O}_{2}$ and penta-BDE exposure............................50

Chapter 5: Conclusion and Future Direction.....................................52

Chapter 6: References............................................................54 


\section{List of Tables}

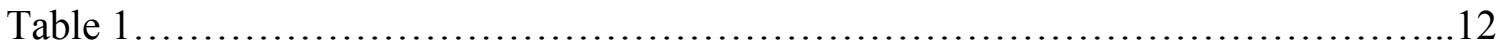




\section{List of Figures}

Figure 1: Elevated Oxygen Levels.........................................19

Figure 2: Chemical Structure of Polybrominated Diphenyl Ethers....................20

Figure 3: Chemical structure of penta-BDE..................................20

Figure 4: Lewis dot structure of hydrogen peroxide.............................20

Figure 5: MTT assay for cell viability using hydrogen peroxide on HEK293T cells.....29

Figure 6: MTT assay for cell viability using penta-BDE on HEK293T cells..............30

Figure 7: (A) Protein bands of p120 Nrf1, p95 Nrf1, and Nrf2 after $\mathrm{H}_{2} \mathrm{O}_{2}$ treatment......31

Figure 7: (B) Protein levels of p120 Nrf1, p95 Nrf1, and $\mathrm{Nrf} 2$ after $\mathrm{H}_{2} \mathrm{O}_{2}$ treatment......31

Figure 8 (A): Protein bands of p120 Nrf1, p95 Nrf1, and Nrf2 after penta-BDE

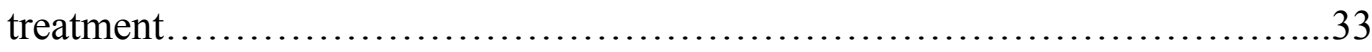

Figure 8 (B): Protein levels of p120 Nrf1, p95 Nrf1, and Nrf2 after penta-BDE

treatment...........................................................33

Figure 9: Protein carbonyl assay run on HEK293T cells treated with $\mathrm{H}_{2} \mathrm{O}_{2} \ldots \ldots \ldots \ldots \ldots 36$

Figure 10: Protein carbonyl assay run on HEK293T cells treated with penta-BDE.......37

Figure 11: 8-Isoprostane assay run on HEK293T cells treated with $\mathrm{H}_{2} \mathrm{O}_{2} \ldots \ldots \ldots \ldots \ldots . .38$

Figure 12: 8-Isoprostane assay run on HEK293T cells treated with penta-BDE.........39

Figure 13: Luciferase reporter assay run on HEK293T cells treated with $\mathrm{H}_{2} \mathrm{O}_{2} \ldots \ldots \ldots . .42$

Figure 14: Luciferase reporter assay run on HEK293T cells treated with penta-BDE.....43

Figure 15: Activity level of beta-galactosidase enzyme in HEK293T cells after $\mathrm{H}_{2} \mathrm{O}_{2}$

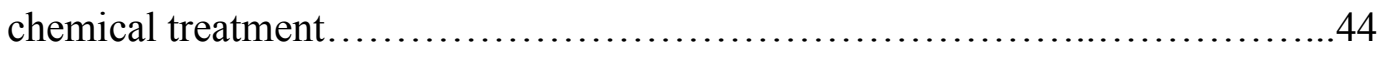

Figure 16: Activity level of beta-galactosidase enzyme in HEK293T cells after penta- 
BDE chemical treatment................................................45 


\section{List of Abbreviations}

AChE - 8-isoprostane-acetylcholinesterase

ARE - Antioxidant response element

ATCC - American Type Culture Collection

ATP - Adenosine triphosphate

ATSDR - Agency for Toxic Substances and Disease Registry

Bach - BTB-basic leucine zipper transcription factors

bZIP - Basic leucine zipper domain

CAT - Catalase

CBP - CREB-binding protein

$\mathbf{C}_{12}$ FDG - 5-Dodecanoylaminofluorescein Di- $\beta$-D-Galactopyranoside

CNC - Cap'-n'-collar

CPRG - Chlorophenol red- $\beta$-D-galactopyranoside

CREB - cAMP response element-binding protein

DMEM - Dulbecco's Modified Eagle Medium

DMSO - Dimethyl sulfoxide

DNA - Deoxyribonucleic acid

DNPH - 2, 4-dinitrophenylhydrazine

DTT - Dithiothreitol

EpRE - Electrophile response element

ER - Endoplasmic reticulum

FBS - Fetal bovine serum 
Gclc/GCLC - Glutamate-cysteine ligase catalytic subunit

Gclm - Glutamate-cysteine ligase regulatory subunit

GCS - glutamylcysteine synthetase

Gpx1 - Glutathione peroxidase 1

Gstp1 - Glutathione S-Transferase Pi 1

Gstp2 - Glutathione S-Transferase Pi 2

Gstm3 - Glutathione S-Transferase Mu 3

Gstm6 - Glutathione S-Transferase Mu 6

Gsta1 - Glutathione S-Transferase Alpha 1

HEK293T - Human embryonic kidney cells transfected

Hmox1 - Heme oxygenase 1

$\mathbf{H}_{2} \mathbf{O}_{2}-$ Hydrogen peroxide

Keap1 - Kelch-like ECH-associated protein 1

LOAEL - Lowest observed-adverse-effect level

Maf-Musculo-aponeurotic fibrosarcoma oncogene

Mt1 - Metallothionein 1

Mt2 - Metallothionein 2

NAD(P)H - Nicotinamide adenine dinucleotide phosphate

NCS - Newborn calf serum

NOAEL - No-observed-adverse-effect level

Nrf - Nuclear factor-erythroid 2 subunit-related transcription factors

NWRC - National Wildlife Research Centre

NQO1 - NAD(P)H:quinone reductase 
PBDE - Polybrominated diphenyl ether

PCB - Polychlorinated biphenyl

PEI - Polyethyleneimine

Penta-BDE - Penta-brominated diphenyl ether

PMSF - Phenylmethylsulfonyl fluoride

RNA - Ribonucleic acid

ROS - Reactive oxygen species

SEM - Standard error of the mean

SOD1 - Superoxide dismutase

UGT - UDP-glucuronosyltransferases 


\section{Chapter 1: Introduction}

\section{1: Oxidative Stress, ROS, Free Radicals}

The increase in oxygen levels in the Earth's atmosphere allowed for the evolution of aerobic organisms that use dioxygen as the final electron acceptor in the process of breaking down energy sources, allowing a higher energy yield in comparison to fermentation or anaerobic respiration (Scandalios, 1993). For instance, in aerobic metabolism, the total breakdown of one molecule of glucose yields 38 molecules of the energy molecule ATP, while the anaerobic breakdown of the same one molecule yields only 8 ATPs (Scandalios, 1993). In its ground state, molecular dioxygen is relatively stable and unreactive, but it is capable of producing lethal, reactive, excited states molecules in forms of free radicals (Scandalios, 1993).

The oxygen that we breathe is converted to water in a reaction catalyzed by cytochrome oxidase of complex IV in the electron transport chain of the inner mitochondrial membrane. Cytochrome oxidase is the last electron acceptor in the chain and must give up its reducing equivalents in order to allow continued electron movement down the chain; if electron movement stops, the proton motive force dissolves and ATP production halts. Thus, in aerobic species, the key function of oxygen is to act as a sink or dump for electrons (Cadenas \& Davies, 2000).

Although this system is very efficient, the very nature of alternating oxidation reduction reactions allows each electron carrier to participate in side reactions with oxygen. For example, as ubiquinone cycles between its fully oxidized and fully reduced forms, there is a chance for an electron to pass to oxygen forming oxygen radicals instead 
of passing to the next electron carrier in the electron transport chain. There are several enzymes within the electron transport chain that are prone to forming oxygen radicals via side reactions with oxygen, they include: NADH dehydrogenase, NADH oxidase, succinate dehydrogenase, succinate oxidase, and ATPase. These side reactions are the major source of oxygen radicals under normal intercellular conditions (Cadenas \& Davies, 2000).

In addition to these toxic reactions caused by the electron transport chain of the inner mitochondrial membrane, the enzyme monoamine oxidase of the outer mitochondrial membrane also produces large amounts of $\mathrm{H}_{2} \mathrm{O}_{2}$. This enzyme catalyzes the oxidative deamination of biogenic amines and in turn generates large amounts of reactive oxygen species (ROS) within both the mitochondrial matrix and the cytosol (Cadenas \& Davies, 2000). Furthermore, there are non-mitochondrial sources of ROS in the cell, such as the enzyme NADPH oxidase, which reduces oxygen to superoxide radical and in turn produces secondary reactive oxidants, making it the main source of oxidative stress during inflammation (Wu et al., 2003).

When the body produces more ROS than it can neutralize, it is said to be under oxidative stress (Valavanidis et al., 2006; Davies, 1995). ROS can go on to form free radicals, which are the main drivers behind the damage to important cellular and mitochondrial molecules (Sohal et al., 2002). Free radicals cause this damage by removing electrons from the body's molecules in a process called oxidation (Finkel \& Holbrook, 2000). Oxidation may alter the shape of molecules leading to loss of function. Different types of ROS, such as superoxide, hyderogen peroxide, nitric oxide, 
peroxynitite, and the hydroxyl radical, cause oxidative damage to DNA, lipids, and proteins (Finkel \& Holbrook, 2000).

Some studies align the capacity to neutralize $\mathrm{H}_{2} \mathrm{O}_{2}$ with the capacity to deal with oxidative stress (Oliver \& Brooke, 2016; Kaneuchi et al., 2003). Other studies have shown that when bovine mammary epithelial cells were treated with $\mathrm{H}_{2} \mathrm{O}_{2}$, there was a time- and dose-dependent inhibition of cell survival, accompanied with sharp increases of ROS (Jin et al., 2016).

Oxidative stress can lead to the production of markers of cellular aging or, more specifically, increased number of carbonyl groups on proteins. Oxidative damage to macromolecules has been quantified by measuring protein carbonyl content (Oliver \& Brooke, 2016; Dalle-Donne et al., 2003; Reznick, 1994). In mice studies, researchers have shown that oxidative stress can increase the amount of carbonyl group modifications on proteins (Tanase et al., 2016). Furthermore, researchers observed, using fluorescence imaging data, an increase of oxidative stress in aging mice (Tanase et al., 2016).

Other studies measured the protein carbonyl content, and concluded that older cells are associated with the greater accumulation of protein carbonyl groups, in both in vitro and in vivo studies (Adachi et al., 1998). As well, these studies showed a link between oxidative stress-mediated protein oxidation and aging (Adachi et al., 1998). Other in vitro evidence shows that the amount of oxidative damage to various macromolecules, such as lipids, proteins, and DNA, increases exponentially with age in a variety of tissues in different species (Sohal et al., 2002; Sohal \& Weindruch, 1996). Others have demonstrated that oxidative damage to proteins must be an important factor in aging, because oxidized proteins lose catalytic and structural integrity and are 
substantially broken down (Sohal et al., 2002; Berlett \& Stadtman, 1997; Stadtman \& Levine, 2000).

The addition of carbonyl groups to proteins causes them to aggregate. Protein aggregation increases autophagy which leads to apoptosis, resulting in aggregate-related cytotoxicity. Proteins also aggregate during normal physiological aging, when proteolytic degradation by the proteasome begins to break down and cellular proteins collect and become insoluble. These proteins have important biological function and as such their loss is detrimental, leading to disorders such as neurodegenerative diseases (Tanase et al., 2016). Protein modifications caused by oxidative stress also include glycation, glycoxidation, lipoxidation and carbonylation, and these have been observed in diseases such as diabetes, metabolic syndrome, chronic inflammation and degenerative conditions (Tanase et al., 2016).

\section{2: Antioxidant Response Element}

The antioxidant response to oxidative stress starts when specific transcription factors bind to an enhancer element known as the antioxidant-response element; also referred to as the electrophile response element (ARE/EpRE), which has the consensus sequence TGCTCAGTCAT (Chepelev et al., 2011a). This enhancer element is located in the promoter and enhancer regions of genes of antioxidant and phase one and two detoxification enzymes. Genes that are expressed under the control of ARE/EpRE include, heme oxygenase-1, ferritin (light and heavy chains), metallothioneines, $\mathrm{NAD}(\mathrm{P}) \mathrm{H}$ quinone (oxido) reductase, glutathione $\mathrm{S}$-transferases, $\beta$-globin, and subunits

of the proteasome (Chepelev et al., 2011a; Jung and Kwak, 2010). The family of 
transcription factors known as the nuclear factor-erythroid 2 subunit-related transcription factors (Nrf1, Nrf2, and Nrf3) regulates gene expression through binding to ARE/EpRE (Chepelev et al., 2013a). These transcription factors are members of the cap'-n'-collar (CNC) basic region leucine zipper (bZIP) family of proteins. These factors bind to small Maf (musculo-aponeurotic fibrosarcoma oncogene) proteins and then go on to either activate or repress gene expression (Chepelev et al., 2013a; Bugno et al., 2015). Other members of the CNC-bZIP family include, Bach1 and Bach2. These proteins also form heterodimers with Maf proteins, but act as dominant repressors of the ARE/EpRE genes (Chepelev et al., 2011a; Bugno et al., 2015).

\section{3: Nuclear Factor-Erythroid 2 Subunit-Related-1 (Nrf1)}

Nrf2 has been shown to be inhibited by Kelch-like ECH-associated protein 1 (Keap1), which it associates with in the cytosol and must be released from in order to be activated by cAMP response element-binding protein (CREB)-binding protein (CBP) (Kawai et al., 2011). CBP acetylates two lysines on Nrf2, which releases it from Keap1 and allows it to travel to the nucleus (Kawai et al., 2011; Cosgrove et al., 2006; Zhang et al., 2006). In the nucleus Nrf2 associates with co-activating small Maf proteins and then binds the ARE/ EpRE to express antioxidant genes. Genes specifically regulated by Nrf2 include NAD(P)H:quinone reductase (NQO1), glutamylcysteine synthetase (GCS), UDPglucuronosyltransferases (UGT), epoxide hydrolase (Thimmulappa et al., 2002).

The Nrf1 protein is an important activator when the cell is under oxidative stress (Kwong et al., 1999). In its full length (p120) form, Nrf1 is anchored to the endoplasmic reticulum (ER) by its $\mathrm{N}$ terminal targeting sequence (Zhang et al., 2007), and is released 
by deglycosylation of its Asn/Ser/Thr-rich (NST) domain (Zhang et al., 2007; Zhang et al., 2009). Before entering the nucleus, Nrf1 must go through further positive regulation by proteolytic cleavage (Wang \& Chan, 2006), and it is the fragments that bind the small Mafs, then bind to the ARE/EpRE and transactivate gene expression. The active nuclear form is p95 Nrf1, while the repressor nuclear form is the p65 Nrf1 (Chepelev et al., 2013b). Other forms and their functionality include: activator p140, activator p120, partial repressors p55, repressor p46, p36, and p25 (Bugno et al., 2015). These forms either need further processing to become the shorter nuclear active p95 form, or have gone through too much cleavage, where they have lost their transactivation domains. p65 Nrf1 has the DNA-binding domains and is able to bind the ARE/EpRE, but lacks one of the transactivation domains, causing it to act as a dominant negative inhibitor of full length Nrf1 and Nrf2, stopping them from binding to ARE (Chepelev et al., 2013b).

The genes activated by Nrf1, when the cell is under oxidative stress, include but are not limited to: glutamate-cysteine ligase catalytic subunit (glutathione synthesis enzyme) (Gclc), glutamate-cysteine ligase regulatory subunit (glutathione synthesis enzyme) (Gclm), glutathione peroxidase 1 (selenium-dependent enzyme that catalyzes the breakdown of hydrogen peroxide) (Gpx1), heme oxygenase 1 (enzyme involved in heme degradation) (Hmox1), metallothioneins 1 and 2 (metal-binding proteins) (Mt1 and Mt2), and different forms of glutathione S-transferase (involved in detoxification) (Gstp1, Gstp2, Gstm3, Gstm6, and Gsta1) (Bugno et al., 2015).

Studies show Nrf1 to be essential for development. Nrf1 but not Nrf2 global knockout mice, are embryonic lethal after embryonic day 12.5 (Bugno et al., 2015). Other studies show an overlap between Nrf1 and Nrf2 function in liver development where 
double mice mutants died before embryonic day 10 (Bugno et al., 2015). These effects are linked with impaired expression of antioxidant genes, oxidative stress, and increased sensitivity to death via oxidant generation (Bugno et al., 2015).

\section{4: Cellular Senescence}

Among many theories, the genetic theory of aging states that there are programmed signals with timed functional changes that cause the cell to age, through the shortening of telomeres and declines in hormonal and immunologic function (Tosato et al., 2007). After a certain period of time, our bodies send out a signal to reduce the repair process and to start the degradation process (Tosato et al., 2007). The specific time is different for different organisms; for example a fruit fly lives for 30 days (Carey et al., 1998), a mouse for 3 years (Langston et al., 1999), a turtle for 100 years (Gibbons, 1987), and a Redwood tree lives for 1000 years (Lewington \& Parker, 1999). These signal genes are called genetic timers and they are specific sequences of DNA that govern each stage of the body's development and determine the next appropriate step in the aging process (Olovnikov, 2003). These genes keep track of the body's progress and thus control the age at which certain events occur (Hayflick Limit) (Tosato et al., 2007). There are other genes that are called death genes, and these genes tell the body to deteriorate and die (Saltsman, 2005).

Chemical pollutants that produce more ROS than the body's antioxidant defenses can neutralize will cause oxidative stress leading to inflammation, tissue damage, disease, and aging. This can also contribute to protein modification and the accumulation of protein carbonyl groups, which is often used as an indicator of cellular aging (Sohal et 
al., 2002). ROS can also go on to form free radicals, which are the main reason behind the damaging effects leading to aging and age-related disease (Sohal et al., 2002). Because free radicals are highly reactive, they cause damage by reacting with the body's molecules and by extracting electrons, thus damaging the macromolecule and causing a chain reaction of radical formation (Finkel \& Holbrook, 2000). This damage may cause excess blood clotting, cataracts, and atherosclerosis (Finkel \& Holbrook, 2000).

Although mild amounts of oxidative damage, such as that experienced during exercise, can be easily combated by the body's antioxidant defenses, such toxic reactions contribute greatly to the aging process and form the central dogma of the Free Radical Theory of Aging (Finkel \& Holbrook, 2000). This theory states that ROS produce free radicals, which go on to damage biomolecules via oxidation and cause aging and agerelated diseases (Beckman \& Ames, 1998). Cellular and mitochondrial DNA, RNA, and proteins are subject to modifications by oxidative stress, and these oxidatively damaged products are selectively degraded by nucleases and proteases. Apoptosis induced by oxidative stress involves an early break down of mitochondrial polynucleotides (both DNA and RNA), most likely by a calcium-activated mitochondrial nuclease (Finkel \& Holbrook, 2000). This process comes before apoptotic nuclear DNA fragmentation but occurs at the same time as the increase of mitochondrial membrane permeability and the release of mitochondrial cytochrome $c$. Partially digested mitochondrial polynucleotides and released cytochrome $c$ play similar roles in that they both activate pro-apoptotic enzymes (Finkel \& Holbrook, 2000). Studies have shown that oxidative damage to mitochondrial enzymes, and to the mitochondrial genome itself, have a huge impact on many age-related degenerative processes (Finkel \& Holbrook, 2000). 
Several studies have shown that oxidatively damaged lipids tend to accumulate with age, due to decrease in functionality of antioxidant enzymes, weakened repair systems, and excess amounts of damaging ROS (Wang et al., 1995; Pacifici \& Davies, 1991). Growing evidence shows that oxidative damage is a factor that contributes to the aging process, though it is one of several factors thought to be involved in the process (Pacifici \& Davies, 1991).

Studies done in marrow stromal cells examined changes in bone mass during the aging process and the effects that lipid oxidation might have on bone aging (Parhami, 2003). It was observed that oxidized lipids take part in the gradual impairment of premature bone cells' potential to differentiate. These damaging actions are pronounced with age and in the age-related disease osteoporosis. The agent isoprostane 8isoprostaglandin $\mathrm{E}_{2}$ (which is an isoprostane similar to 8-iso prostaglandin $\mathrm{F}_{2 \alpha}$; both produced from the oxidization of arachidonic acid) has been implicated in the inhibition of osteoblastic differentiation (Parhami, 2003). It has been reported that an increase in age correlates with an increase in lipid peroxide levels, which also correlates with an increase in the levels of ROS, promoting the oxidative breakdown of cellular molecules (Beckman \& Ames, 1998). Oxidative damage to cellular biomacromolecules may accelerate the aging process and this damage may promote the generation of more ROS in a forward feedback loop. In turn, oxidatively damaged biomolecules (ex. lipids), cause negative effects on bone development and reabsorption, leading to the reduction in bone mass and density (Parhami, 2003).

Other studies have shown that with senescence comes an accumulation of lipofuscin (partial lysosomal degradation of lipids), the alteration of antioxidant defense 
systems, and the decrease of gene expression involved in antioxidant defenses (Jervis \& Robaire, 2004). Jervis and Robaire (2004) looked at oxidative stress and aging in the rat epididymis and observed all these effects. They concluded that oxidative stress is associated with the aging process, that there is an age-related accumulation of oxidative damage, and that there is increased longevity with the lessening of oxidative stress (Jervis \& Robaire, 2004).

\section{5: Polybrominated Diphenyl Ethers}

Polybrominated diphenyl ethers (PBDEs) are manufactured flame retardants that are used in many products including insulation, textiles, building materials, plastics, electronics, and foams (Frouin, et al., 2010). Large quantities of these chemicals were

produced and distributed in the past decades, resulting in widespread contamination of the environment, and bioaccumulation in foods, and are still persistent in the environment (Lefevre et al., 2015). PBDEs and their metabolites have been found in blood, adipose tissue, and the liver of fish, birds and mammals, as well as in human blood, serum, adipose tissue, breast milk and placental tissue (Agency for Toxic Substances and Disease Registry (ATSDR), 2004). Constant exposure from house dust and breast milk leads to toddlers and infants having the highest body burdens of these chemicals, refer to Table 1, which shows the presence of these chemicals in placental tissue from various countries (Tagliaferrir et al., 2010; Ma et al., 2012). In vitro studies on neuronal cells show that PBDEs induce oxidative stress by altering the intracellular oxidant/antioxidant balance, and others have shown that they cause apoptotic cell death (Tagliaferrir et al., 
2010). In vivo studies show PBDEs-induced neurotoxic effects, in particular in the early stages of brain development (Tagliaferrir et al., 2010). 
Table 1: The presence of flame retardants (BDE-47 and BDE-99) in the placental tissues sampled from various countries (ng/g weight) (Ma et al., 2012)

\begin{tabular}{|l|l|l|l|l|}
\hline Country & N & BDE-47 & BDE-99 & Reference \\
\hline China & 130 & $4.6 \times 10^{-3}$ & $3.5 \times 10^{-3}$ & Ma et al., 2012 \\
\hline Spain & 100 & 0.25 & 0.12 & Gomara et al., 2007 \\
\hline Denmark & 50 & 0.32 & 0.23 & Frederiksen et al., 2009 \\
\hline USA & 5 & 0.49 & 0.46 & Dassanayake et al., 2009 \\
\hline
\end{tabular}


According to the ATSDR's report in 2004, PBDEs and their metabolites cause oxidative stress through the production of free radicals and ROS (ATSDR, 2004). These products of oxidative stress are the main reason behind the damage to biomolecules that may lead the cell to aging or may cause the organism to develop age related diseases. Organisms have low molecular weight antioxidants, as well as antioxidant enzymes, in their cells that protect from such damage, but over time, even these are depleted or damaged themselves, leading to cellular aging (ATSDR, 2004).

The ATSDR has no-observed-adverse-effect levels (NOAELs) and lowest observed-adverse-effect levels (LOAELs) values based on animal models for many PDBEs congeners. These are a NOAEL of $1 \mathrm{mg} / \mathrm{kg} /$ day and a LOAEL of $3 \mathrm{mg} / \mathrm{kg} / \mathrm{day}$ (ATSDR, 2004).

\section{6: Toxicological Background of PBDEs}

PBDEs are widely distributed throughout the environment and have been found in all biotic and abiotic matrices worldwide (Letcher et al., 2014). Higher molecular weight congeners are less bioactive and tend to persist in the environment, while lower molecular forms (tri- to hexa-BDEs) are almost completely absorbed and slowly eliminated (McDonald, 2002). Under UV light exposure, higher molecular weight PBDEs are easily degraded to lower molecular weight PBDEs and thus with time chemicals that have accumulated in the soil become bioactive and are leeched into the water ways or into the air (Shih \& Wang, 2009). There is evidence of PBDE transport via air, in similar manner as chlorinated dioxins and furans (McDonald, 2002). 
Previous studies of PBDEs concentrations in humans reported levels of up to 400 $\mathrm{ng} / \mathrm{g}$ in lipid tissues, and this was shown to be on the rise in some populations (McDonald, 2002). Based on toxicity data, structural similarities, and mechanistic similarities to polychlorinated biphenyls (PCBs), the toxic endpoints associated with PBDEs are likely to be thyroid hormone disruption, neurobehavioral toxicity, and for some congeners cancer (McDonald, 2002).

The mechanisms behind PBDE toxicity are still unclear, with some studies suggesting that the hydroxylated metabolites (OH-BDE) are the main cause of oxidative stress being associated with cellular damage and apoptosis (Ji et al., 2011). These metabolites have also been connected to DNA damage via the blocking of replication and subsequent chromosomal breaks (Ji et al., 2011).

As PBDEs are simple additives to polymers, they can easily leach out of the product and into the environment (Costa et al., 2008). PBDEs have been shown to be persistent organic pollutants that bioaccumulate in the environment, biomagnify up the food chain, and can be detected in high amounts in animals and humans (Costa et al., 2008). The main sources of chemical exposure are diet based, where PBDEs can leach out of plastic containers and into food, though indoor air and occupational exposure have been documented. The highest concentrations of contaminants among foods are in fish (3276 pg/g), meats (1378 pg/g), and dairy products (485 pg/g) (Costa et al., 2008). Regardless of the type of food, exposure to PBDEs from foods is the highest in the U.S. (60- $84 \mathrm{ng} /$ day), and Europe (38-97 ng/day) (Costa et al., 2008).

Among humans, infants have the highest body burden of PDBEs. PBDEs have been detected in human breast milk, with levels of $956 \mathrm{ng} / \mathrm{g}$ in North America in 2005, 
and $24.6 \mathrm{ng} / \mathrm{g}$ in Europe in 2003 (Costa et al., 2008). As well as in breast milk, PBDE levels in serum have been increasing in the past few decades in the general population (Costa et al., 2008).

PBDEs are distributed to the liver, kidneys, and the thyroid gland after long term exposure. Different PBDEs have different toxicities with the larger deca-BDE being the least potent and least bioactive, while the smaller congeners are more easily absorbed, metabolized, and eliminated. For example, the NOAEL for deca-BDE is in the grams $/ \mathrm{kg} /$ day, while for penta-BDE it is in the milligrams $/ \mathrm{kg} /$ day. (Costa et al., 2008)

Toxicokinetic studies in animals have shown that absorption, metabolism and excretion of PBDEs depend on the specific congener, on the species, and on the gender of the animal. For example, the lower brominated forms are broken down into mono- and di-hydroxylated metabolites, which are toxic and tend to accumulate in the serum, while the larger deca-BDE is broken down into the lower brominated forms (Costa et al., 2008).

Some evidence shows that PBDEs are endocrine disruptors, where they disrupt the levels of androgenic, estrogenic, and thyroid hormones activities (Darnerud, 2008). Studies in humans show exposure to PBDEs have adverse effects on male reproduction associated with alternations to steroid hormone levels (Johnson et al., 2013; Turyk et al., 2008), and decreases in sperm count and quality (Meeker \& Stapleton, 2010; Abdelouahab et al., 2011). Previous studies report that high levels of PBDEs detected in follicular fluid or in serum is associated with a longer time to conceive (Harley et al., 2010) and with failure of embryo implantation after in vitro fertilization (Johnson et al., 2012). Studies on PBDEs in animal models show adverse effects that include disruption 
to the endocrine system (Darnerud, 2008; Legler, 2008) and other effects associated with diabetes, cancer, neurobehavioral and developmental disorders (Kim et al., 2014). Studies have also shown that the time point at which animals are exposed to PBDEs is important because perinatal exposure results in clear disruptions in the onset of puberty and in gametes production in both male and female rats (van der Ven et al., 2009; Ema et al., 2008).

\section{7: Current Concern and Regulations on PBDEs}

As of 2015, the Government of Canada (Chemical Management Division) has documented that PBDE levels in Canadian biota are rising, with reports showing increases in tissue concentrations, with penta-, octa-, and deca-brominated diphenyl ethers being the most commercially available mixtures (Chemical Management Division (CMD), 2015). The highest levels in the environment are associated with industrialized regions; however, PBDEs are also found in the Arctic, which suggests long range atmospheric transport of these compounds (CMD, 2015).

In December 2006, Environment Canada and Health Canada promised to reduce the concentration of PBDEs in the environment to the lowest possible level and published the Risk Management Strategy for PBDEs (CMD, 2015). This strategy uses a multilevel approach to achieve the outcome and combines regulatory and voluntary methods, development of environmental quality controls, international cooperation, and ongoing national monitoring (CMD, 2015).

In July 2008, the Government of Canada in, a means to protect the Canadian environment, published the Polybrominated Diphenyl Ethers Regulations and restricted 
the manufacture and use of these chemicals in Canada, thus reducing their release into the environment (CMD, 2015). Specifically, this document prohibits the manufacture of the following forms of PBDEs: tetraBDE, pentaBDE, hexaBDE, heptaBDE, octaBDE, nonaBDE, and decaBDE congeners. Under the Canadian Environmental Protection Act, 1999, the congeners tetra, penta, and hexa meet the criteria for elimination, and thus under the Regulations, they are prohibited from being used, sold, bought, or imported into Canada (CMD, 2015).

It is clear that even though PBDEs are highly regulated in Canada, they are still prevalent in the environment and their effects are still present. This is why I chose to work with PBDEs. I wanted to work with a chemical that is relevant and that was used in a variety of products that are important to consumers.

\section{8: Cell Lines Used}

Human Embryonic Kidney (HEK293T) cells were chosen for this study because they are a model cell line in which the presences of Nrfl and Nrf2 have already been observed (Chepelev et al., 2013a). They are metabolically active and immortalized, meaning they do not have a Hayflick Limit and should not show any signs of the aging process, in terms of morphology or proteomics (Xia et al., 2008; Kavsan et al., 2011), making them a great cell model to use in our studies. Lastly, they have the ability to accept external DNA by means of transfection with high efficiency rates (Thomas \& Smart, 2005).

\section{9: Hypothesis and Objectives}


The focus of this Master's thesis is to show that penta-BDE causes oxidative stress and that this oxidative stress can lead to aging. It is predicted that increasing exposure to PBDEs will cause oxidative injury to the cell that will elicit the antioxidant response and cause the increased activity of senescence-associated beta-galactosidase. To test out this hypothesis we first used a positive control for the induction of oxidative stress and then tested to see if PBDE treatments lead to the same outcomes. Hydrogen peroxide $\left(\mathrm{H}_{2} \mathrm{O}_{2}\right)$ (Figure 4) is a pro-oxidant and, when converted to the highly reactive hydroxyl radical, can induce the oxidation of DNA, RNA, and proteins (refer to Figure 1) (D’Orazio et al., 2013).

Therefore, the objective of this study is to examine the effects of exposure to PDBEs (Figure 2), more specifically penta-brominated diphenyl ether (Figure 3). To show oxidative stress, we measured the antioxidant response, the amount of oxidized proteins, and the amount of oxidized lipids. To show that PDBE-derived oxidative stress leads to increased levels of markers of cellular senescence, we measured the levels of activity of the senescence-associated beta-galactosidase enzyme. Human embryonic kidney cells are used as a model system for testing due to their high metabolic activity and DNA transfectability. 


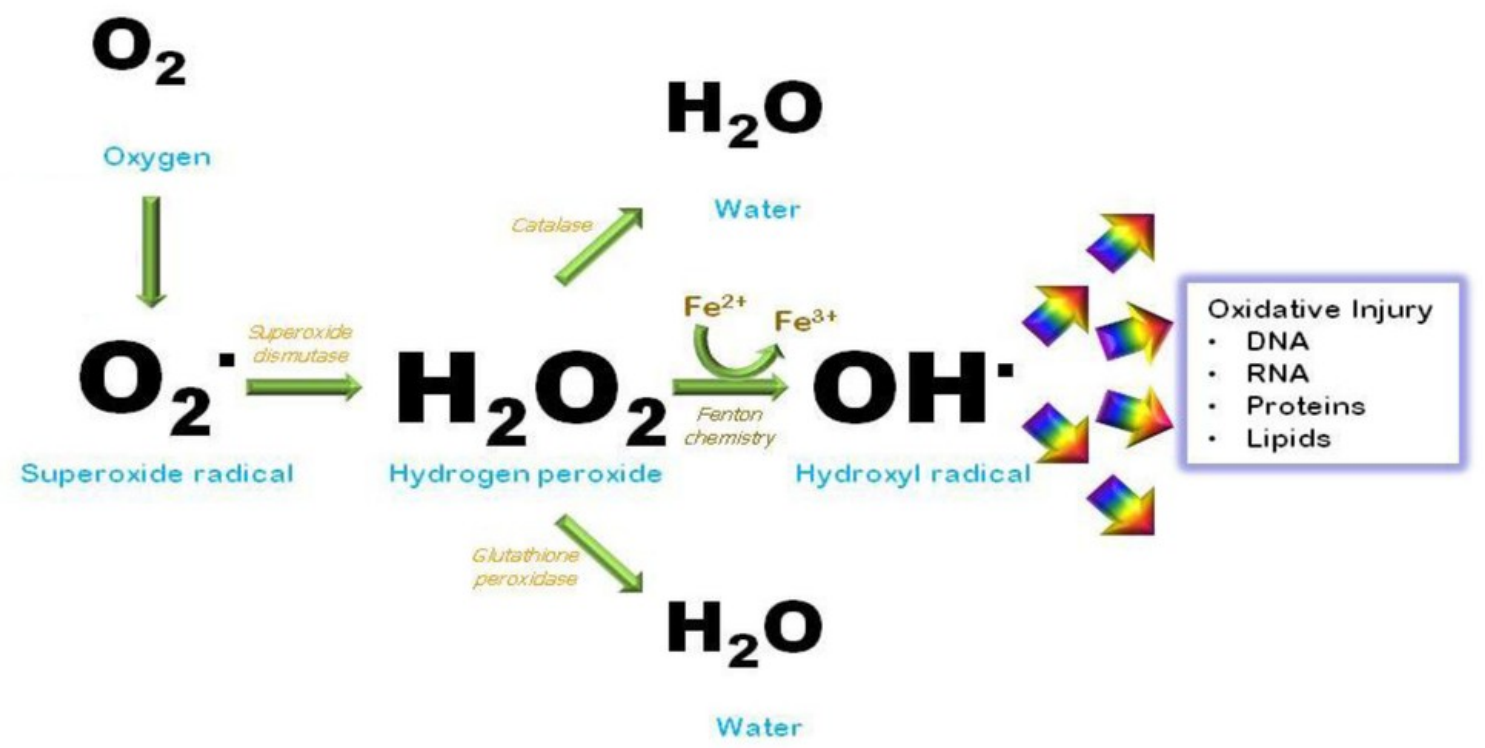

Figure 1: Elevated oxygen level is the first step in the process of forming free radicals and causing oxidative injury. Taken and modified from D'Orazio et al., 2013. 


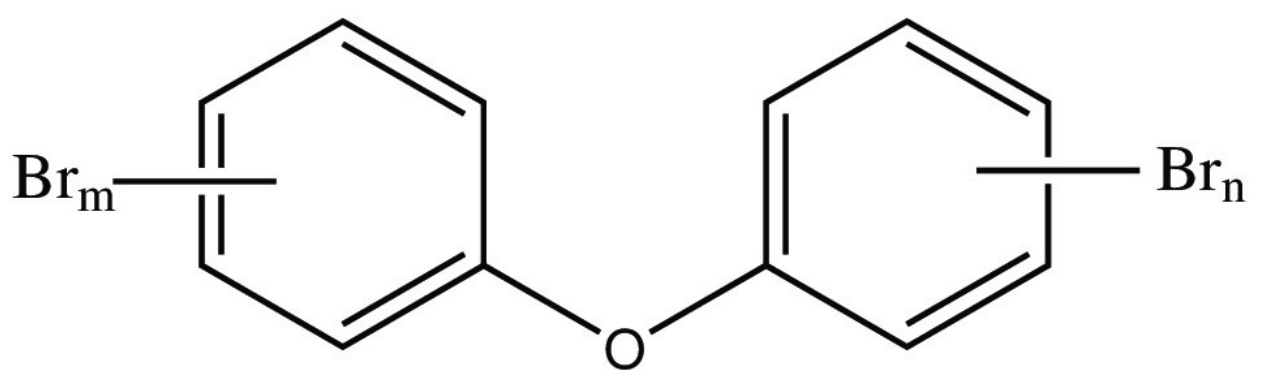

Figure 2: Chemical structure of polybrominated diphenyl ethers, where $m+n$ can range from four to ten bromines.

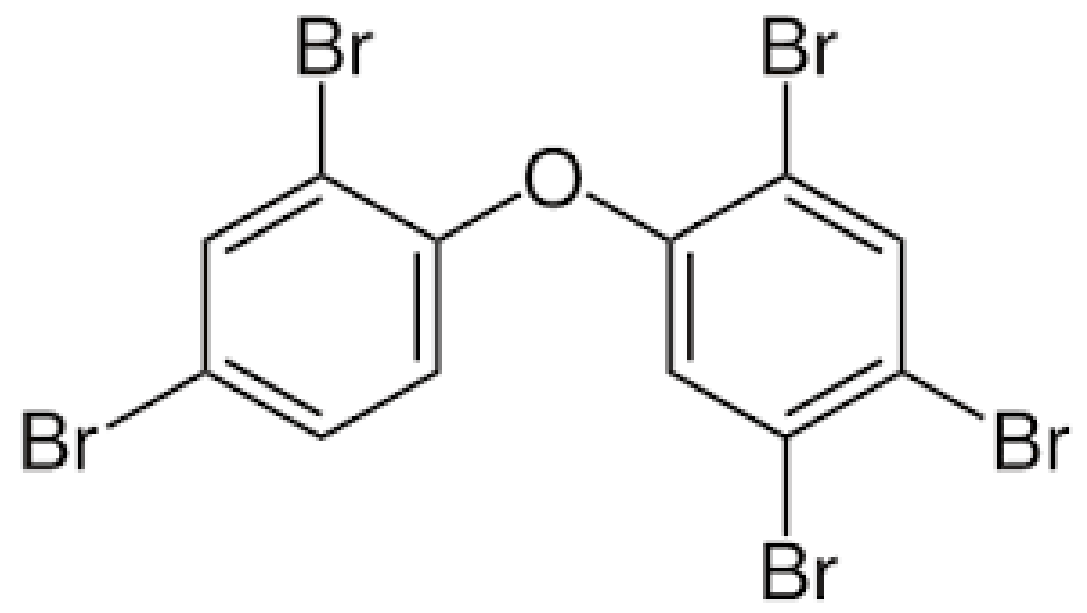

Figure 3: Chemical structure of penta-BDE, also commonly known as BDE-99, showing the total number of bromines on the two phenyl rings as five.

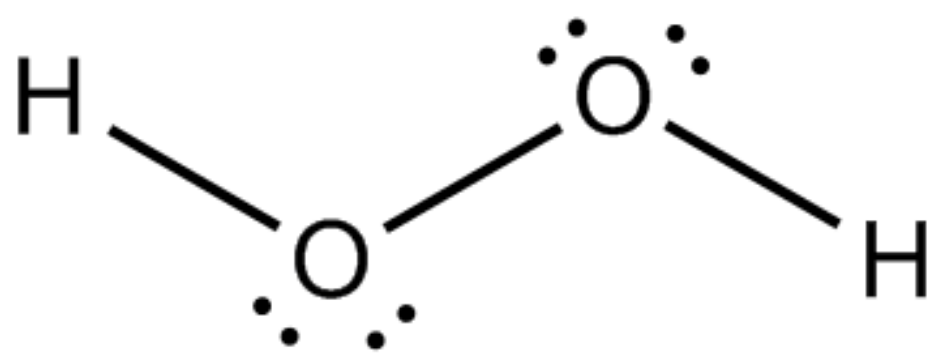

Figure 4: Lewis dot structure of hydrogen peroxide, showing its proposed shape and the reactivity of the oxygens due to the electron lone pairs. 


\section{Chapter 2: Materials and Methods}

\section{1: Cells}

Human embryonic kidney cells (HEK293T) were purchased from the American Type Culture Collection (ATCC, Manasses, VA). Cells were cultured in Dulbecco's Modified Eagle Medium (DMEM) supplemented with 5\% fetal bovine serum (FBS) and 5\% newborn calf serum (NCS) (Gibco, Grand Island, $\mathrm{NY}$ ), incubated in $5 \% \mathrm{CO}_{2}$ at $37^{\circ} \mathrm{C}$ and $95 \%$ humidity.

\section{2: Chemicals and Reagents}

Hydrogen peroxide (30\%) was purchased from Sigma-Aldrich (Oakville, Ontario) and diluted to working concentrations of 100 and $1000 \mu \mathrm{M}$ using ultrapure water. When diluting the stock chemical, its concentration was confirmed using absorbance spectrum. Working concentrations were kept in dark $4^{\circ} \mathrm{C}$ fridge.

Penta-brominated diphenyl ether (penta-BDE) was received as a highly pure powder form from the National Wildlife Research Centre (NWRC; Environment and Climate Change Canada) and diluted to working concentrations of 1 and $10 \mathrm{mM}$ using sterile dimethyl sulfoxide (DMSO) under sterile conditions (Stapleton et al., 2004). Working concentrations were kept at room temperature in the dark.

Anti-Nrf1 (H4), anti-Nrf2 (C-20), goat anti-mouse-HRP and goat anti-rabbit-HRP were purchased from Santa Cruz Biotechnologies, Inc. (Dallas, Texas). Anti-beta-tubulin (E-7) was purchased from the Developmental Studies Hybridoma Bank (Iowa City, Iowa). 


\section{3: MTT Assay}

Cells were plated in a 96 well tissue culture plate at a volume of $200 \mu \mathrm{L}$ per well and concentration of 50,000 cells $/ \mathrm{mL}$ and left to grow overnight. The next day, cells were treated with varying concentrations of either $\mathrm{H}_{2} \mathrm{O}_{2}(0,1,5,8,10,15,20,25,30,35,40$, $45,50,55,60,70,80 \mu \mathrm{M} ; 2$ hours $)$ or penta-BDE $(0,5,10,15,20,25,30,35,40,45,50$, $55,60 \mu \mathrm{M} ; 24$ hours). The treatment durations were selected based on literature research, ( 2 hours for $\mathrm{H}_{2} \mathrm{O}_{2}$ from Jin et al., 2016 and 24 hours for penta-BDE from Tagliaferri et al., 2010). The treatment durations were also based on MTT viability assays showing low cell survival rates at longer treatment times (data not shown). After the treatment period, the treatment media was removed replaced with fresh media. MTT (3-(4,5dimethylthiazol-2-yl)-2,5-diphenyltetrazolium bromide) (Bio-Rad, Hercules, California) reagent was added at a volume of one tenth of that of the fresh media and concentration of $0.5 \mathrm{mg} / \mathrm{mL}$, and the mixture was left to incubate for $1-2$ hrs at $37^{\circ} \mathrm{C}$ and $5 \% \mathrm{CO}_{2}$ and $95 \%$ humidity. After the incubation period, the media containing the MTT was removed and $100 \mu \mathrm{L}$ of DMSO was added to each well. Once the DMSO dissolved the precipitate, the plate was read in a microplate reader at the wavelength of $530 \mathrm{~nm}$ with a background subtraction of $630 \mathrm{~nm}$. This MTT assay was repeated three times (on independent days) for both hydrogen peroxide and penta-BDE.

\section{4: Western Blotting}

Cells were plated at a concentration of $5.0 \times 10^{5}$ per well in a 6 well plate and allowed to grow overnight. The next day, each well was treated with the $0,1,5,10,15$, or $20 \mu \mathrm{M}$ of either $\mathrm{H}_{2} \mathrm{O}_{2}$ or penta-BDE and left to incubate for 2 hours $\left(\mathrm{H}_{2} \mathrm{O}_{2}\right)$ or 24 hours 
(penta-BDE). After the treatment period, cells were harvested and lysed using RIPA buffer (Thermo Fisher Scientific, Ottawa, Ontario), supplemented with 100 and $500 \mu \mathrm{M}$ dithiolthreitol (DTT). Protein concentration of samples was determined using the Pierce BCA Protein Assay Kit (Thermo Fisher Scientific, Ottawa, Ontario). Samples were loaded onto an SDS-PAGE gel $(150 \mathrm{~V}, 300 \mathrm{~mA}, 1.5$ hours at room temperature) with 50 $\mu \mathrm{g}$ of total protein per well.

After the gel was run, proteins were transferred to PVDF (polyvinylidene fluoride) membrane overnight at $4^{\circ} \mathrm{C}$. Cell extracts on PVDF membranes were probed with the following antibodies diluted in Tris-buffered saline with Tween-20 (TBST): Nrf1 (H4) (1:1000) with goat anti-mouse-HRP (1:2000); Nrf2 (C-20) (1:1000) with goat anti-rabbit-HRP (1:2000); and beta-tubulin (E-7) (1:1000) with goat anti-rabbit-HRP (1:2000). This Western blot was repeated three times (on independent days) for both hydrogen peroxide and penta-BDE.

\section{5: Protein Carbonyl Assay}

Cells were plated at a concentration of $5.0 \times 10^{5}$ per well in a 6 well plate and allowed to grow overnight. The next day, the media was replaced with fresh media and cells were treated with the following concentrations $0,1,5,10,15$, or $20 \mu \mathrm{M}$ of either $\mathrm{H}_{2} \mathrm{O}_{2}$ or penta-BDE and left to incubate for 2 hours $\left(\mathrm{H}_{2} \mathrm{O}_{2}\right)$ or 24 hours (penta-BDE). The cells were harvested and the protocol according to the Protein Carbonyl Colorimetric Assay Kit, (Cayman Chemical, Ann Arbor, Michigan) was followed precisely. In short, this assay uses the 2, 4-dinitrophenylhydrazine (DNPH) to measure the protein carbonyl

content in cell lysate sample. The amount of protein-hydrozone product formed is 
measured spectrophotometrically at an absorbance between 360-385 $\mathrm{nm}$. No changes were made to the protocol and each chemical treatment was repeated three times on independent days.

\section{6: 8-Isoprostanes Assay}

Cells were plated at a concentration of $5.0 \times 10^{5}$ per well in a 6 well plate and allowed to grow overnight. The next day, the media was replaced with fresh media and cells were treated with the following concentrations $0,1,5,10,15$, or $20 \mu \mathrm{M}$ of either $\mathrm{H}_{2} \mathrm{O}_{2}$ or penta-BDE and left to incubate for 2 hours $\left(\mathrm{H}_{2} \mathrm{O}_{2}\right)$ or 24 hours (penta-BDE). The cells were harvested and the protocol according to the 8-Isoprostane ELISA Kit (Cayman Chemical, Ann Arbor, Michigan) was followed precisely. In short, this assay is based on the competition between 8 -isoprostane and 8-isoprostane-acetylcholinesterase (AChE) conjugate (8-Isoprostane Tracer) for a limited number of 8-isoprostane specific rabbit antiserum binding sites. The concentration of 8 -isoprostane tracer is constant while the concentration of 8-isoprostane varies according to the sample, giving the relationship of the amount of tracer bound is inversely proportional to the concentration of 8 -isoprostane present. The distinct yellow product of the enzymatic reaction can be measured at 412 $\mathrm{nm}$, and the intensity of the colour is proportional to the amount of tracer bound and inversely proportional to the amount of 8-isoprostane present in each sample. No changes were made and each chemical treatment was repeated three times on independent days.

\section{7: Luciferase Reporter Assay}


Cells were plated at a concentration of $3.0 \times 10^{5}$ cells per well in a 6 well plate and left to grow overnight. The next day, the culture media was replaced with fresh media 30 mins prior to transfection. Ten $\mu \mathrm{L}$ of the $10 \mathrm{x}$ stock of transfection reagent polyethyleneimine (PEI) was diluted in $100 \mu \mathrm{L}$ Opti-MEM (Gibco, Grand Island, New York). The following plasmids were also diluted in $100 \mu \mathrm{L}$ Opti-MEM: $0.4 \mu \mathrm{g}$ betagalactosidase in pCR3.1 vector, $6 \mu \mathrm{g}$ GCLC in pCR3.1 vector, and $4 \mu \mathrm{g}$ pCR3.1 empty vector. The GCLC-ARE-luciferase reporter plasmid was a gift from Dr. Dale A. Dickinson (University of Alabama) and its construction has been described elsewhere (Mulcahy et al., 1997). This plasmid, with three copies of the GCLC AREs/EpREs, provides information on the activity of the Nrf transcription factors when they bind to the ARE/EpRE and the amount of luminescence is measured. The diluted PEI was added to the diluted DNA and the mixture was vortexed 5 times for 5 seconds every 3 minutes for a total of 15 minutes. The mixture was then added drop wise to each well, leaving one well with just cells as the untransfected control.

After 24 hours incubation, the transfection media was replaced with fresh media and left for another 24 hours. The cells were then harvested and lysed using Luciferase Lysis Buffer (25 mM glycylglycine, $15 \mathrm{mM} \mathrm{KH}_{2} \mathrm{PO}_{4}, 15 \mathrm{mM} \mathrm{MgSO}_{4}, 4$ mM EDTA, 1 mM DTT, 1\% Triton X-100, 1x Protease Inhibitor (Bioshop, Burlington, Ontario)). The lysates were centrifuged at the max speed for 15 minutes, and the protein supernatant was used in the subsequent steps.

Ten $\mu \mathrm{L}$ of cell lysates were combined with $76 \mu \mathrm{L}$ of Luciferase Assay Buffer (25 mM glycylglycine, $15 \mathrm{mM} \mathrm{KH}_{2} \mathrm{PO}_{4}, 15 \mathrm{mM} \mathrm{MgSO}_{4}, 4$ mM EDTA, 2 mM DTT, $2 \mathrm{mM}$ ATP) in a 96 well white bottom plate. Each well was injected with $50 \mu \mathrm{L}$ Luciferin 


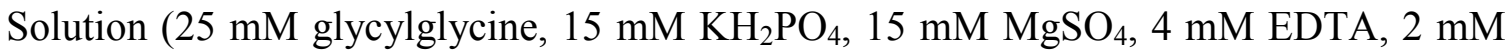
DTT, $200 \mu \mathrm{M}$ Luciferin) and the luminescence was measured using a FLUOstar OPTIMA (BMG Labtech) microplate reader.

Afterwards, $50 \mu \mathrm{L}$ of the luciferase lysate was transferred to a clear bottom 96well plate and combined with $85 \mu \mathrm{L}$ of Beta-Galactosidase Assay Buffer (60 mM $\mathrm{Na}_{2} \mathrm{HPO}_{4}, 10 \mathrm{mM} \mathrm{KCl}, 1 \mathrm{mM} \mathrm{MgCl} 2,1 \mathrm{mM}$ DTT, $0.2 \mathrm{mg} / \mathrm{mL}$ chlorophenol red- $\beta$-Dgalactopyranoside (CPRG)). The plate was incubated at $37^{\circ} \mathrm{C}$ for 30 minutes to $1 \mathrm{hr}$ and then read at $570 \mathrm{~nm}$ with a background subtraction at $630 \mathrm{~nm}$.

The luciferase readings were divided by the beta-galactosidase readings and the ratio was graphed against the concentrations of either $\mathrm{H}_{2} \mathrm{O}_{2}$ or penta-BDE treatment.

\section{8: Flow Cytometry for Measuring Senescence Associated Beta-Galactosidase Activity}

Cells were plated at a concentration of $5.0 \times 10^{5}$ per well in a 6 well plate and allowed to grow overnight. The next day, the media was replaced with fresh media and cells were treated with the following concentrations $0,1,5,10,15$, or $20 \mu \mathrm{M}$ of either $\mathrm{H}_{2} \mathrm{O}_{2}$ or penta-BDE and left to incubate for 2 hours $\left(\mathrm{H}_{2} \mathrm{O}_{2}\right)$ or 24 hours (penta-BDE). Whole cell collection was performed and the protocol according to Debacq-Chainiaux et al. (2009) was followed precisely. The lysosomal alkalinization in the procedure was removed as it was found to be an unnecessary step (Noppe et al., 2009). According to the authors of this modification, $\mathrm{pH}$ modulation had no apparent effect on senescenceassociated beta-galactosidase activity quantification via flow cytometry (Noppe et al., 2009). The substrate used was $\mathrm{C}_{12} \mathrm{FDG}$, a fluorescent substrate of the beta-galactosidase 
enzyme. This fluorescent dye produces a green fluorescent product (Miao et al., 1993), and thus using Filter 1 (for measuring green fluorescence) in the BD Accuri ${ }^{\mathrm{TM}}$ C6 Flow Cytometer (San Jose, California), the amount of fluorescence was measured. This assay was repeated three times (on independent days) for both hydrogen peroxide and pentaBDE.

\section{9: Statistical Analysis}

All values displayed in the Results Section represent the mean \pm the standard error of the mean (SEM) for three independent experiments performed on three independent days. All statistical analyses were made using a one-way ANOVA followed by the Dunnett test, for comparisons to controls $(0 \mu \mathrm{M}$ treatments), with SigmaStat software. Values were considered to be significantly different from one another if the $p$ value was less than or equal to 0.05 . 


\section{Chapter 3: Results}

\section{1: Determination of Chemical Concentrations}

Using human embryonic kidney (HEK293T) cells as the model system and hydrogen peroxide as the positive control for all experiments, cell viability with treatment was tested using the MTT assay. At varying concentrations of chemical treatments, the absorbance was measured, with higher absorbance values being directly proportional to the more viable cells. The treatment duration was 2 hours for hydrogen peroxide and 24 hours for penta-BDE. As the concentration of hydrogen peroxide or penta-BDE increased past $25 \mu \mathrm{M}$, the absorbance decreases below 0.2 units, which shows that fewer cells are viable (Figures 5 and 6). Using this information, the following concentrations were chosen: $0,1,5,10,15$, and $20 \mu \mathrm{M}$. With this, we conducted the rest of the experiments in this study.

\section{2: Increased Chemical Treatment Results in Increased Nrf Protein Expression}

Using the chemical concentrations determined from the MTT assay $(0,1,5,10$, 15 , and $20 \mu \mathrm{M})$ we performed Westerns to show the amount of Nrf1 and Nrf2 protein expression in response to increasing chemical treatment. There was an increase in protein expression with increasing chemical treatment from $0 \mu \mathrm{M}$ (no chemical, just cells) to 20 $\mu \mathrm{M}$ of either chemical (Figures $7 \mathrm{~b}$ and $8 \mathrm{~b}$ ). Both hydrogen peroxide (2 hour treatment) and penta-BDE (24 hour treatment) resulted in increases in both Nrf1 and Nrf2 proteins in HEK293T cells. 


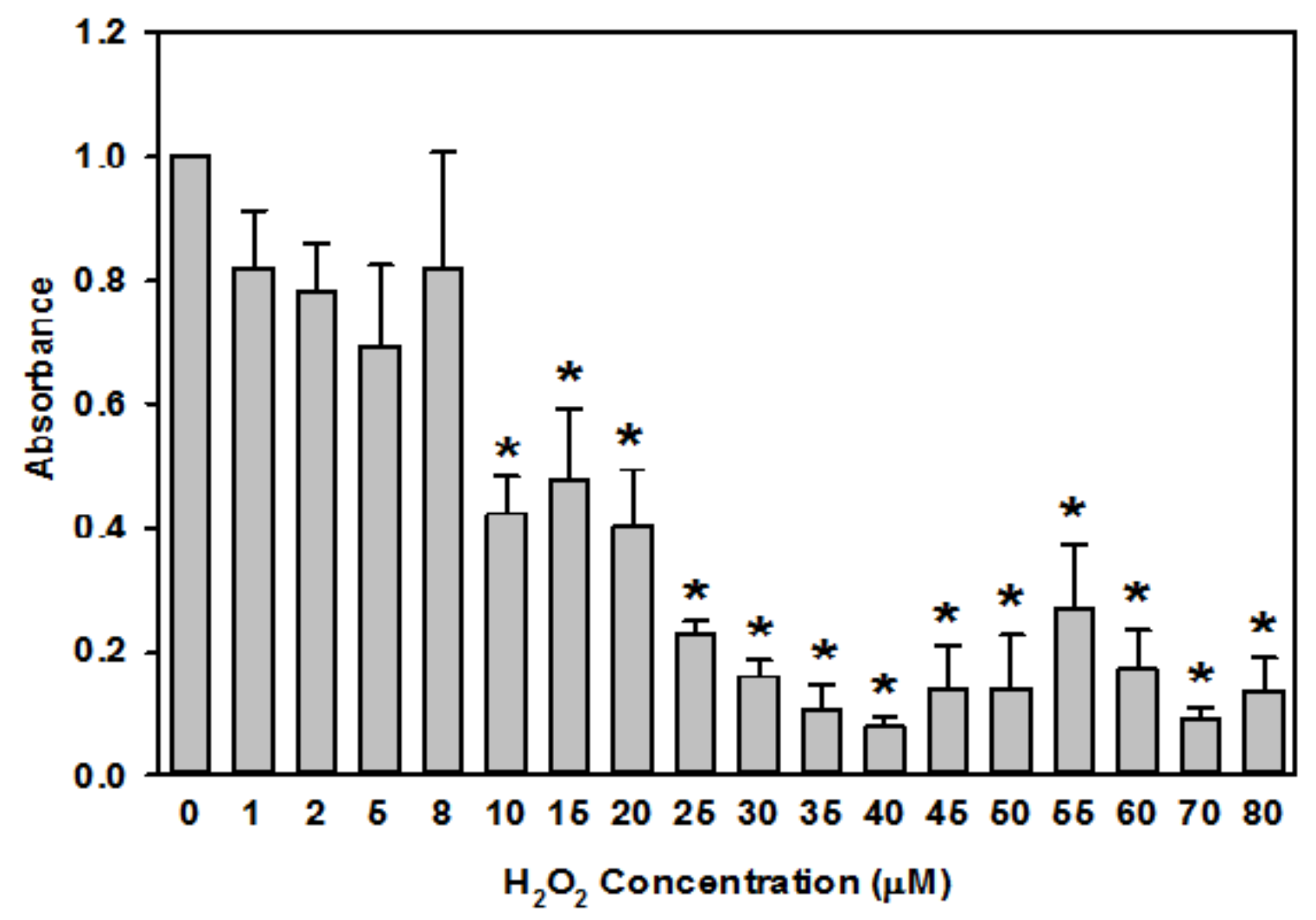

Figure 5: MTT assay for cell viability using hydrogen peroxide on HEK293T cells. With increasing concentrations of hydrogen peroxide (after 2 hour treatment), viability of HEK293T cells decreases with I.C.50 of approximately $20 \mu \mathrm{M}$. Values shown are the means normalized to the control $(0 \mu \mathrm{M}) \pm$ SEM. $N=3,\left(^{*}\right)$ indicates significance $(\mathrm{p}<0.05)$ when compared to the control concentration of $0 \mu \mathrm{M}$. Concentrations of 10 to $80 \mu \mathrm{M}$ show significant decreases in cell survival. Results from one-way ANOVA show significant decreases between means of concentrations. (I.C. 50 is the concentration of the inhibitor, in this case the chemical, where the response of the cells is reduced by $50 \%$ ). 


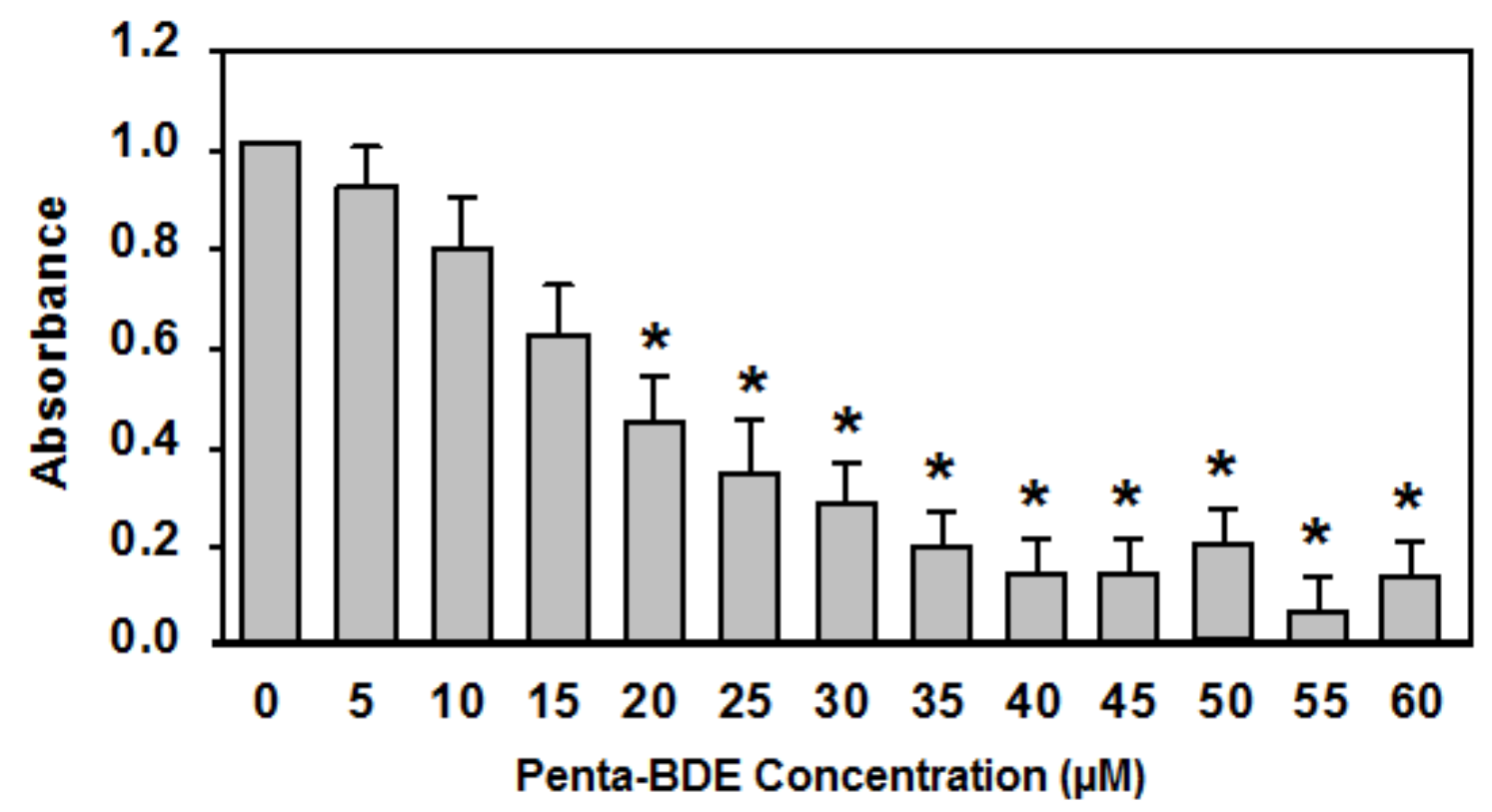

Figure 6: MTT assay for cell viability using penta-BDE on HEK293T cells. With increasing concentrations of penta-BDE (after 24 hour treatment), viability of HEK293T cells decreases with I.C.50 of approximately $20 \mu \mathrm{M}$. Values shown are the means normalized to the control $(0 \mu \mathrm{M}) \pm$ SEM. $N=3,(*)$ indicates significance $(\mathrm{p}<0.05)$ when compared to the control concentration of $0 \mu \mathrm{M}$. Concentrations of 20 to $60 \mu \mathrm{M}$ show significant decreases in cell survival. Results from one-way ANOVA show significant decreases between means of concentrations. (I.C.50 is the concentration of the inhibitor, in this case the chemical, where the response of the cells is reduced by $50 \%$ ). 
(A)

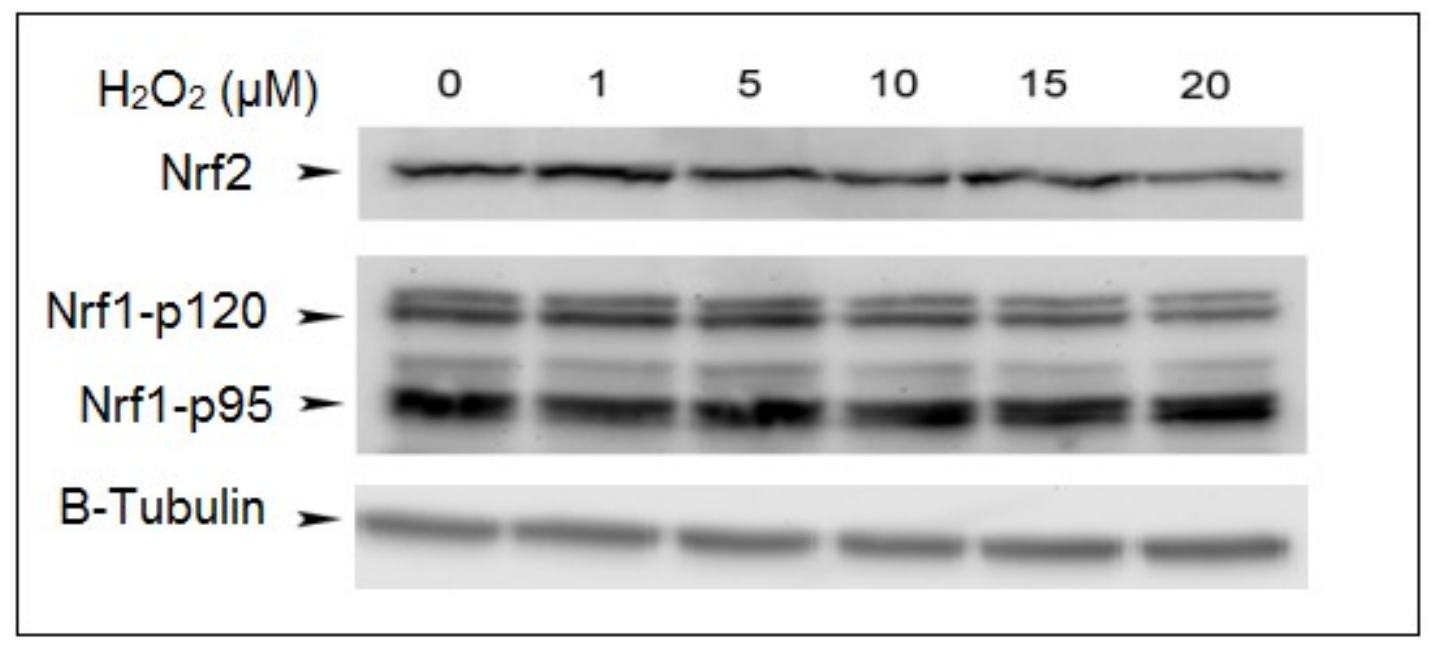

(B)

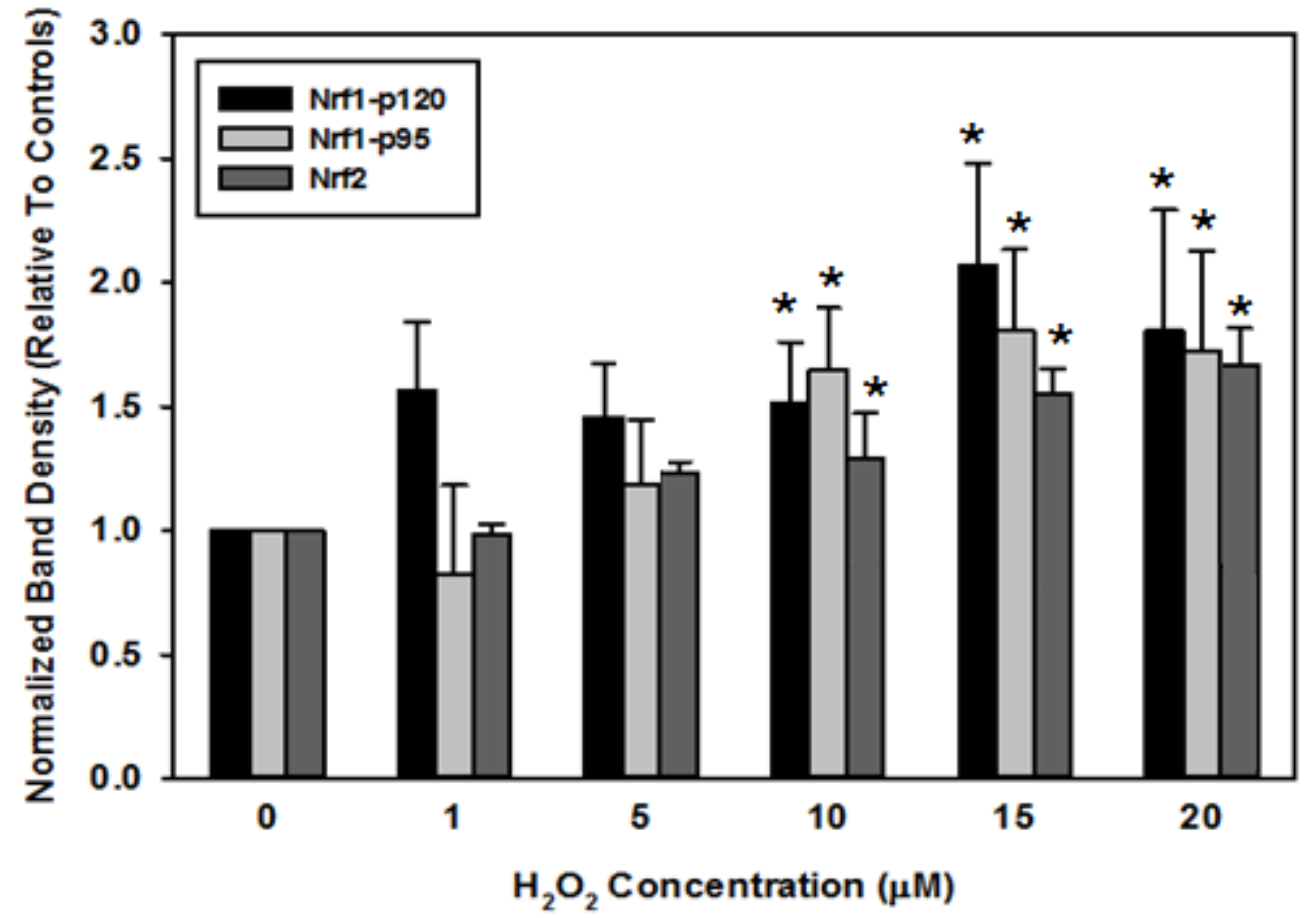


Figure 7: (A) Protein bands of p120 Nrf1, p95 Nrf1, and Nrf2 after $\mathrm{H}_{2} \mathrm{O}_{2}$ treatment. Beta-tubulin was used as a loading control. (B) Protein levels of p120 Nrf1, p95 Nrf1, and Nrf2 after $\mathrm{H}_{2} \mathrm{O}_{2}$ treatment. As chemical concentration increases so does the amount of all three proteins. Values shown are the means normalized to the control $(0$ $\mu \mathrm{M}) \pm$. SEM. $\mathrm{N}=3,(*)$ indicates significance $(\mathrm{p}<0.05)$ when compared to the control concentration of $0 \mu \mathrm{M}$. Concentrations from 10 to $20 \mu \mathrm{M}$ show significant increases in protein levels when compared to the control $(0 \mu \mathrm{M})$. Results from one-way ANOVA show significant increases between means of concentrations. 
(A)

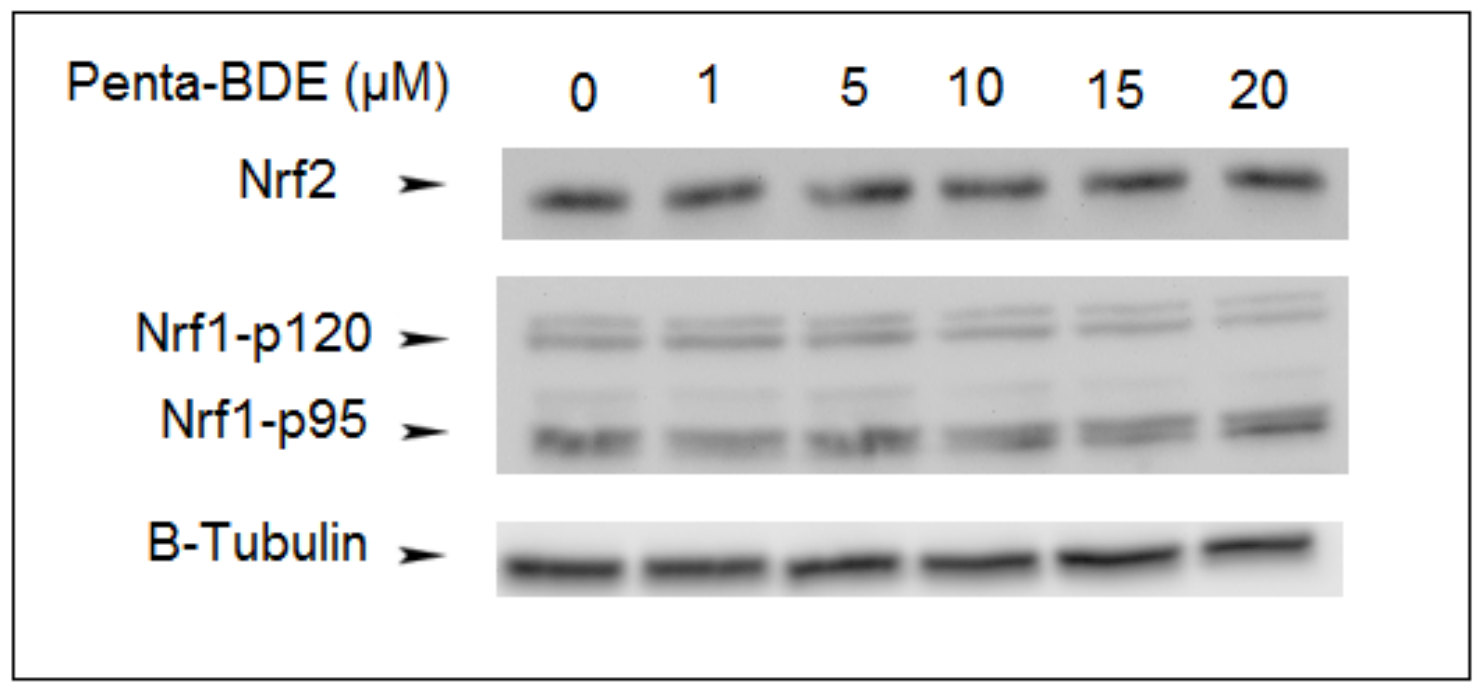

(B)

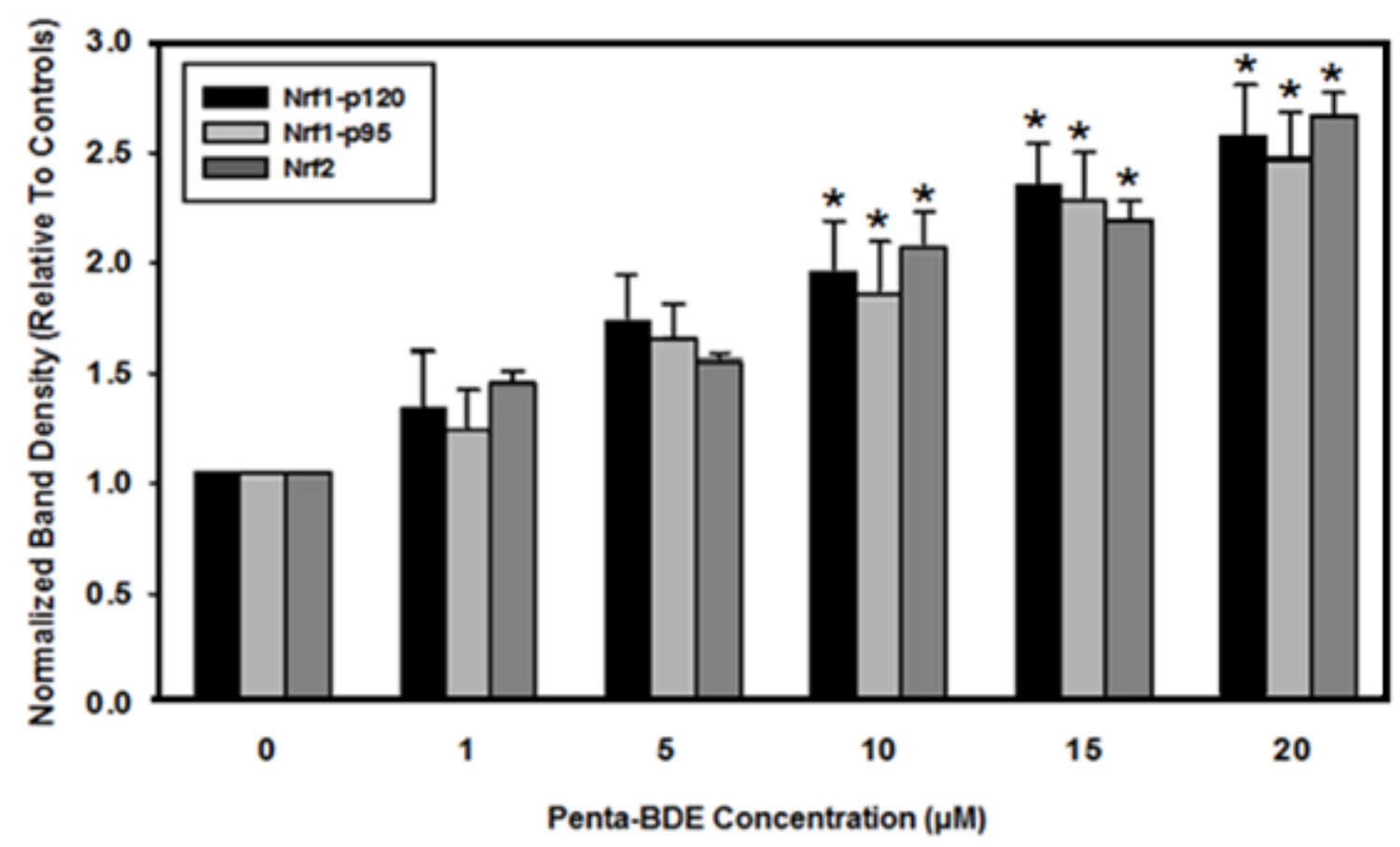


Figure 8: (A) Protein bands of p120 Nrf1, p95 Nrf1, and Nrf2 after penta-BDE treatment. Beta-tubulin was used as a loading control. (B) Protein levels of p120 Nrf1, p95 Nrf1, and Nrf2 after penta-BDE treatment. It is shown that as chemical concentration increases so does the amount of all three proteins. Values shown are the means normalized to the control $(0 \mu \mathrm{M}) \pm$ SEM. $N=3,\left(^{*}\right)$ indicates significance $(p<0.05)$ when compared to the control concentration of $0 \mu \mathrm{M}$. Concentrations from 10 to $20 \mu \mathrm{M}$ show significant increases in protein levels when compared to the control $(0 \mu \mathrm{M})$. Results from one-way ANOVA show significant increases between means of concentrations. 


\section{3: Increased Chemical Treatment Results in Increased Levels of Protein Carbonyl Groups}

To explore the connection between oxidative stress to aging, we conducted a protein carbonyl assay, where the higher amount of carbonyl groups is used as an indicator of the aging process. From Figures 9 and 10, we see that as the concentration of chemical increases, so does the amount $(\mathrm{nmol} / \mathrm{ml})$ of carbonyl groups. After 2 hours of the cells being in hydrogen peroxide treatment, there was a significant increase in protein oxidation levels at 1 to $20 \mu \mathrm{M}$ concentrations (Figure 9) when compared to the control treatment of $0 \mu \mathrm{M}$. After 24 hours of the cells being in penta-BDE treatment, there was a significant increase in protein oxidation levels at 10 to $20 \mu \mathrm{M}$ concentrations (Figure 10) when compared to the control treatment of $0 \mu \mathrm{M}$.

\section{4: Increased Chemical Treatment Results in Increased Levels of 8-Isoprostane}

The levels of 8-isoprostane (8-iso prostaglandin $\mathrm{F}_{2 \alpha}$ ), a product of lipid peroxidation resulting from oxidative stress, was measured. As chemical concentrations increased, so did the amount of the oxidized phospholipid (Figures 11 and 12). After 2 hours of hydrogen peroxide treatment, there was no significant increase in 8 -isoprostane levels (Figure 11) when compared to the control treatment of $0 \mu \mathrm{M}$. After 24 hours of penta-BDE treatment, there was a significant increase in 8-isoprostane levels at 5 to 20 $\mu \mathrm{M}$ concentrations (Figure 12) when compared to the control treatment of $0 \mu \mathrm{M}$. 


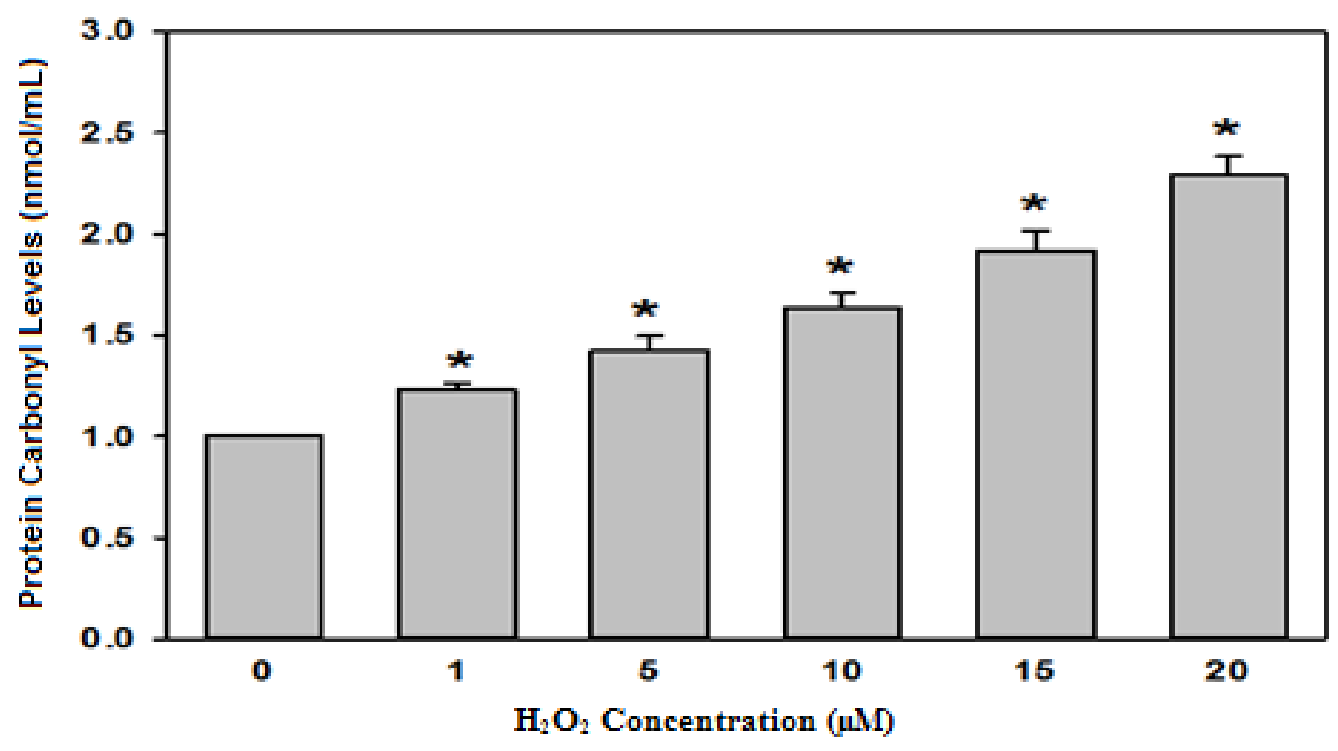

Figure 9: Protein carbonyl assay of HEK293T cells treated with $\mathrm{H}_{2} \mathrm{O}_{2}$. Results show increased levels of total carbonyl groups on proteins in HEK293T cells occurs with increased chemical treatment after 2 hours. Values shown are the means normalized to the control $(0 \mu \mathrm{M}) \pm$ SEM. $\mathrm{N}=3,\left(^{*}\right)$ indicates significance $(\mathrm{p}<0.05)$ when compared to the control concentration of $0 \mu \mathrm{M}$. Concentrations of 1 to $20 \mu \mathrm{M}$ show a significant increase in protein oxidation levels. Results from one-way ANOVA show significant between increases means of concentrations. 


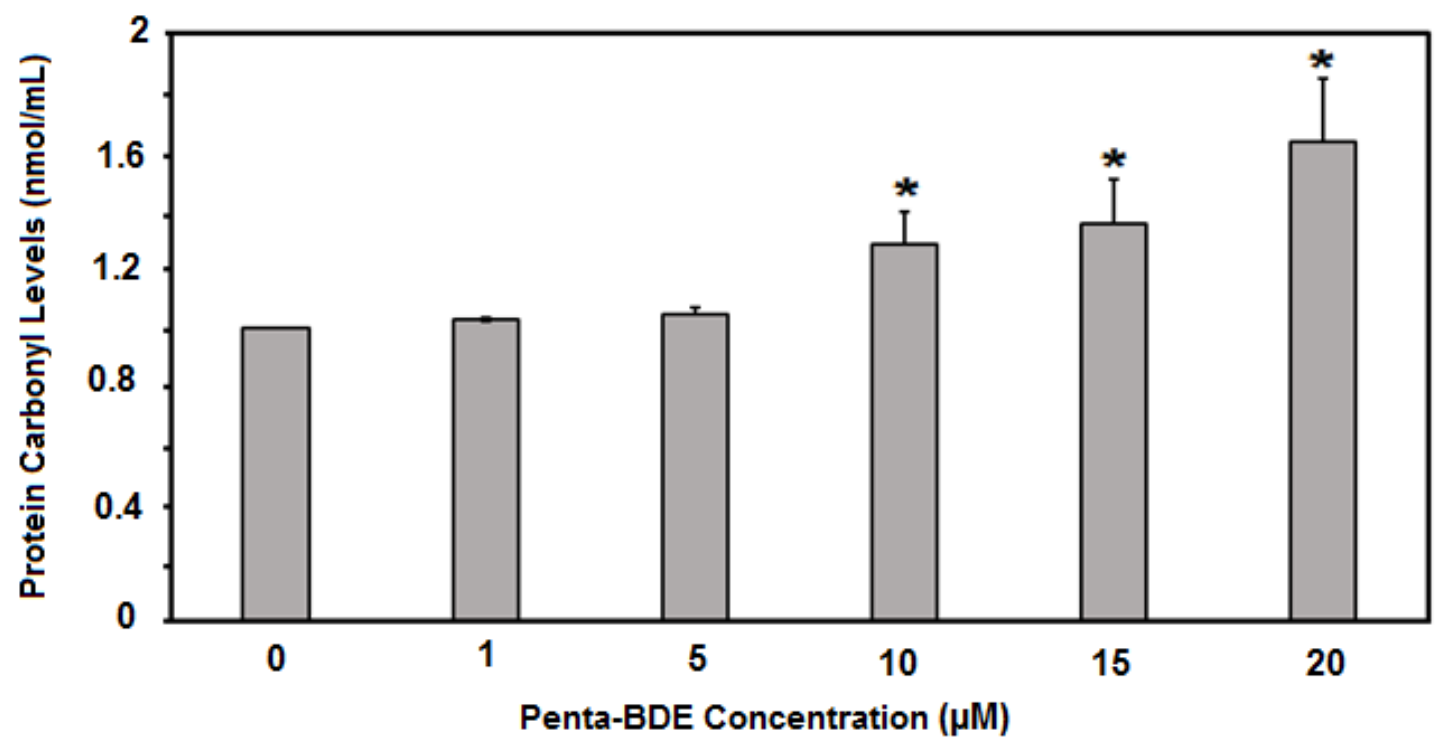

Figure 10: Protein carbonyl assay of HEK293T cells treated with penta-BDE. Results show increased levels of total carbonyl groups on proteins in HEK293T cells with increased chemical treatment after 24 hours. Values shown are the means normalized to the control $(0 \mu \mathrm{M}) \pm$ SEM. $N=3,(*)$ indicates significance $(\mathrm{p}<0.05)$ when compared to the control concentration of $0 \mu \mathrm{M}$. Concentrations of 10 to $20 \mu \mathrm{M}$ show a significant increase in protein oxidation levels. Results from one-way ANOVA show significant increases between means of concentrations. 


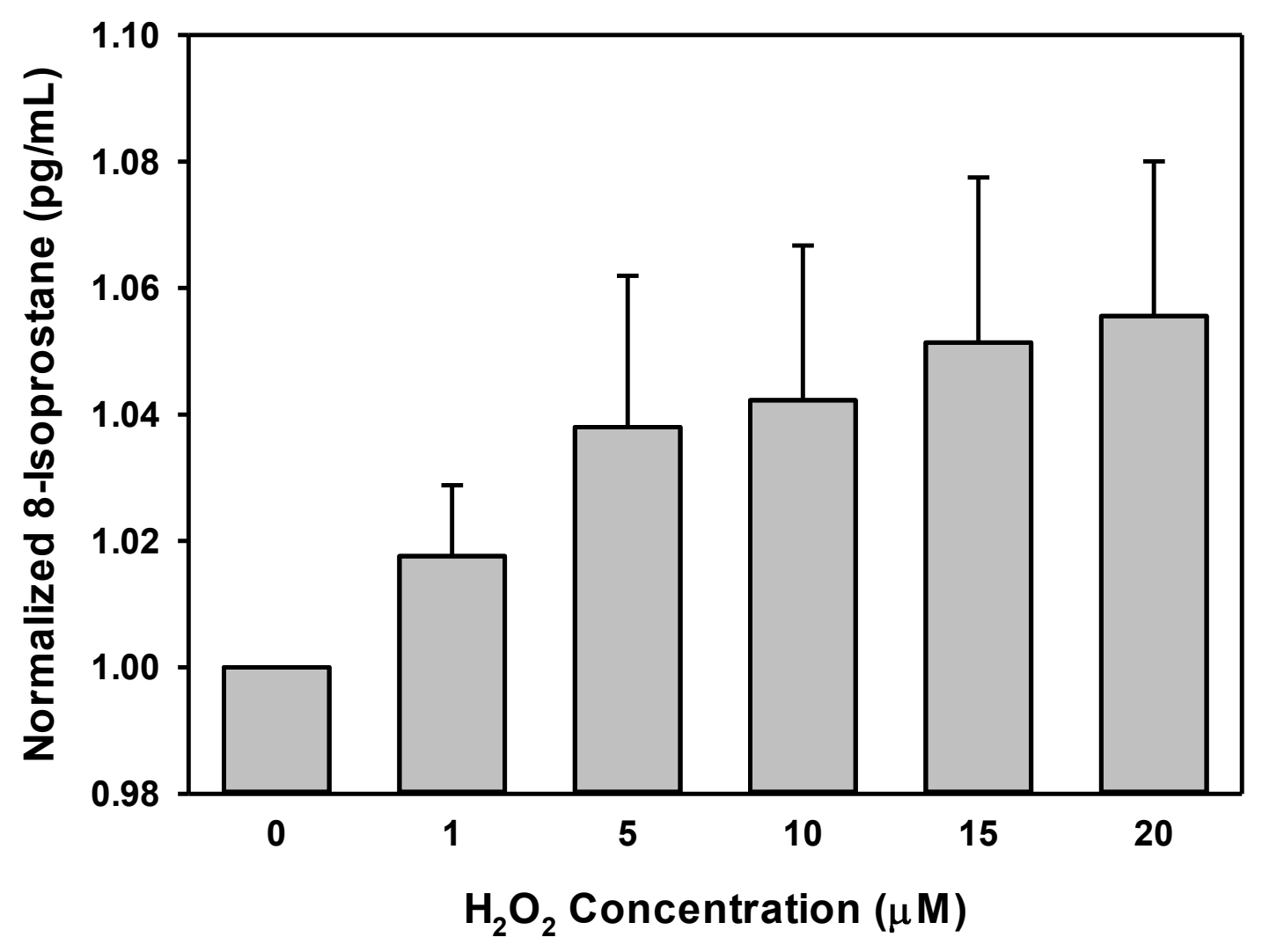

Figure 11: 8-Isoprostane assay of $\mathrm{HEK293T}$ cells treated with $\mathrm{H}_{2} \mathrm{O}_{2}$. Results show an increase in the concentration $(\mathrm{pg} / \mathrm{mL})$ of oxidized lipids with an increase in chemical treatment. Values shown are the means normalized to the control $(0 \mu \mathrm{M}) \pm \mathrm{SEM} . \mathrm{N}=3$. The differences in the mean values among the treatment groups are not great enough to exclude the possibility that the difference is due to random sampling variability; therefore there is no statistically significant difference $(p=0.428)$. 


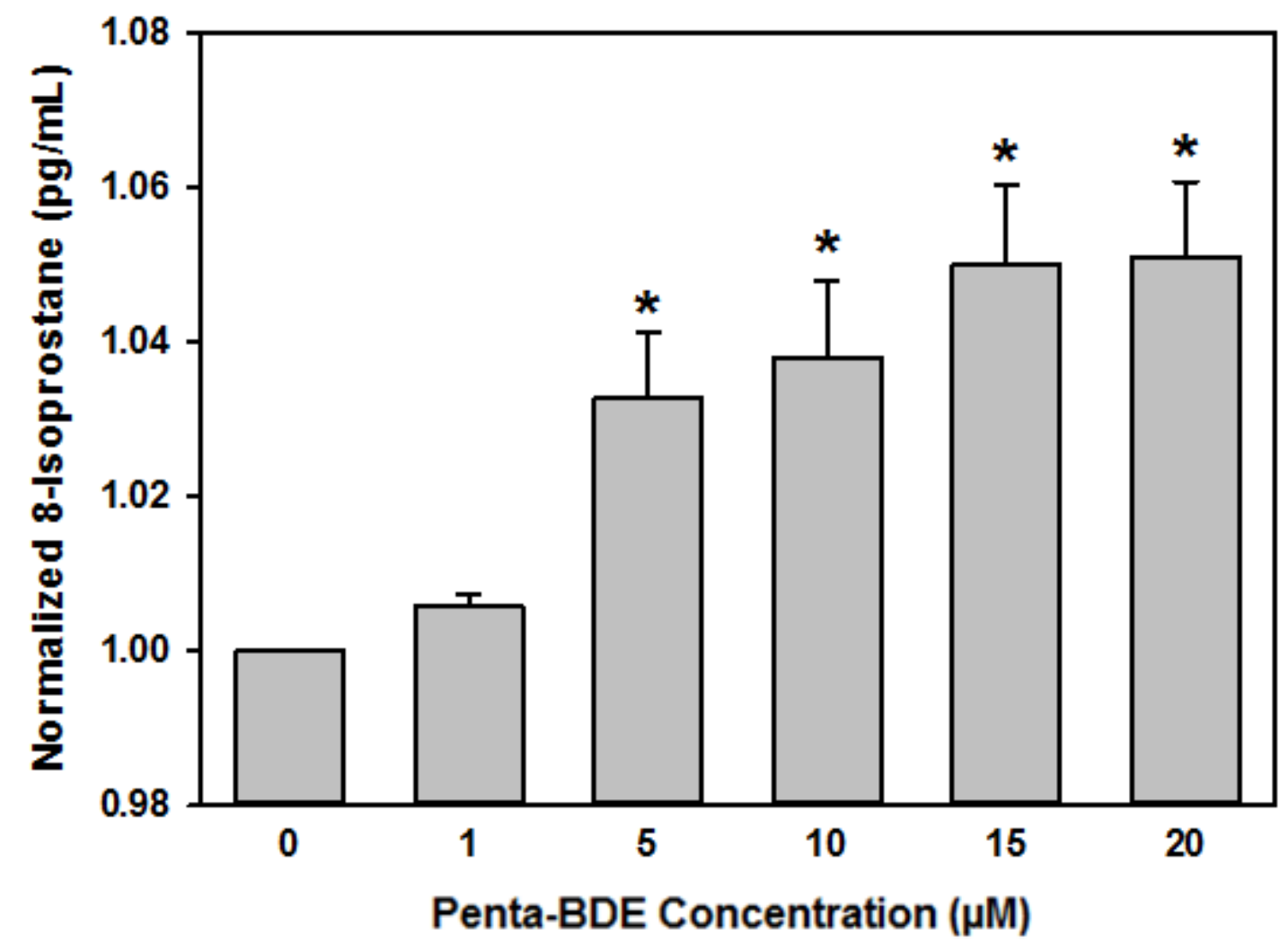

Figure 12: 8-Isoprostane assay of HEK293T cells treated with penta-BDE. Results show an increase in the concentration $(\mathrm{pg} / \mathrm{mL})$ of oxidized lipids with an increase in chemical treatment. Values shown are the means normalized to the control $(0 \mu \mathrm{M}) \pm$ SEM. $\mathrm{N}=3, \quad(*)$ indicates significance $(\mathrm{p}<0.05)$ when compared to the control concentration of $0 \mu \mathrm{M}$. Concentrations of 5 to $20 \mu \mathrm{M}$ show a significant increase in lipid oxidation levels. Results from one-way ANOVA show significant increases between means of concentrations. 


\section{5: Increased Chemical Treatment Results in Increased Nrf1 Transactivation}

\section{Activity}

The luciferase reporter is an important tool widely used in research to measure the transcriptional levels of regulated sequences of DNA (Brasier et al., 1988). In our experiments, the GCLC promoter, containing copies of the ARE/EpRE consensus sequence, was utilized. Results showed an increase in reporter assay activity with increasing chemical concentration (Figures 13 and 14). This observation reflects the oxidative damage that the cell is under and its antioxidant response to such harm. The cell responds via the antioxidant response pathway where the Nrf proteins, specifically Nrf1 and Nrf2 are activated and bind to DNA to transcribe antioxidant genes and phase II detoxification proteins.

\section{6: Increased Chemical Treatment Results in Increased Levels of Beta- Galactosidase Activity Using Flow Cytometry}

During the normal physiological aging process, cells accumulate higher levels of the beta-galactosidase enzyme and its activity is commonly used to measure cellular aging (Dimri et al., 1995; Beattie et al., 1994; Hall et al., 2016). We measured betagalactosidase activity in cells with increasing concentrations of either hydrogen peroxide (after 2 hour treatment) or penta-BDE (after 24 hour treatment). The results showed that as chemical concentration increases, the number of cells with active beta-galactosidase enzyme also increases (Figures 15 and 16). We used flow cytometry for counting fluorescent cells after treating them with chemicals and after treating them with $\mathrm{C}_{12} \mathrm{FDG}$ (5-dodecanoylaminofluorescein di- $\beta$-D-galactopyranoside). $\mathrm{C}_{12} \mathrm{FDG}$ is a fluorogenic 
substrate that once broken down by beta-galactosidase, produces a green fluorescent product that remains within the cell (Miao et al., 1993). 


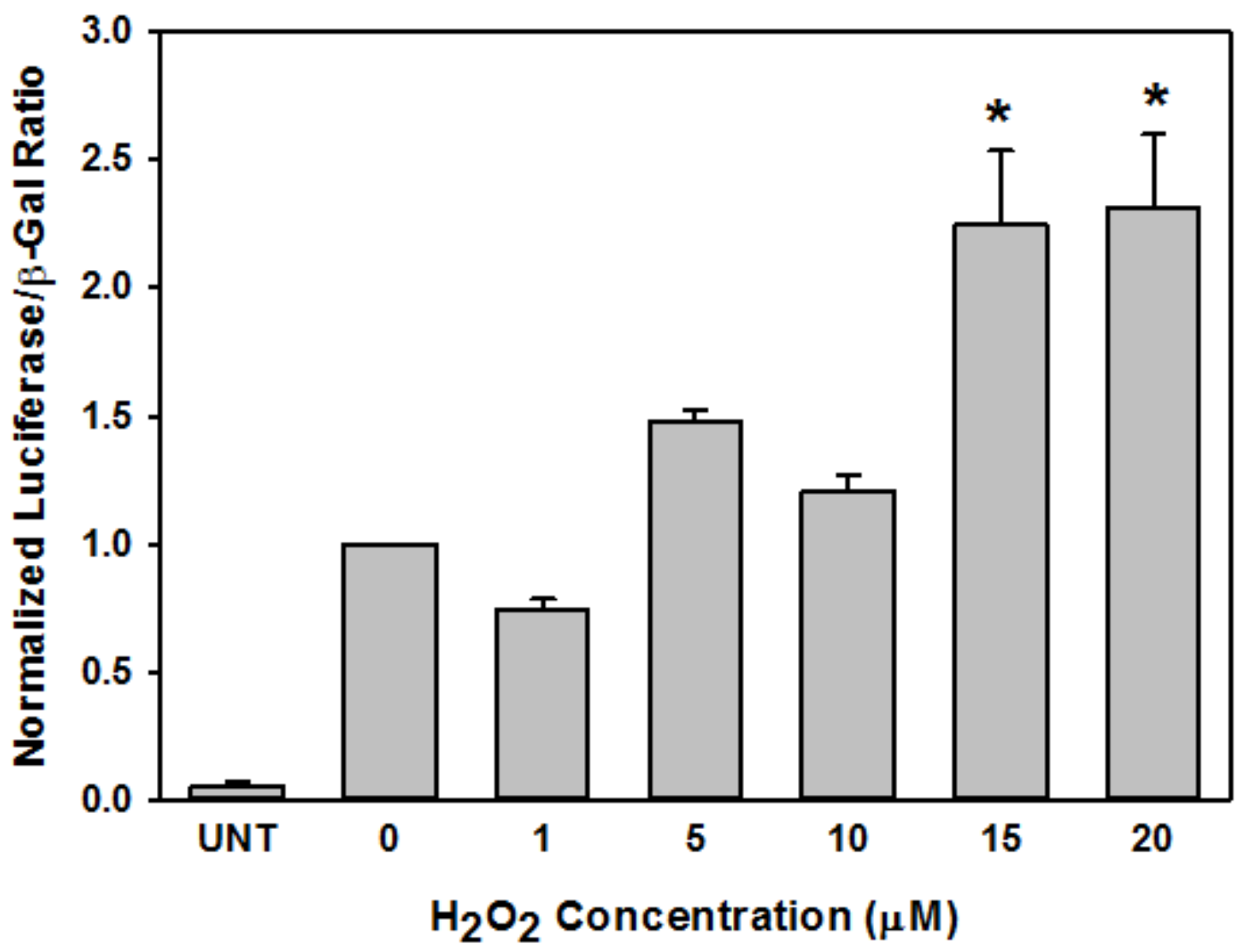

Figure 13: Luciferase reporter assay of HEK293T cells treated with $\mathrm{H}_{2} \mathrm{O}_{2}$. Results show an increase ARE/ EpRE transcription levels with increasing chemical concentrations. This means that the proteins Nrf1 and Nrf2 have an increase in activity level with an increase in chemical treatment. When the cell experiences greater levels of oxidative stress, it will initiate the antioxidant response pathway via Nrf1-ARE and Nrf2ARE. Values shown are the means normalized to the control $(0 \mu \mathrm{M}) \pm \mathrm{SEM} . \mathrm{N}=3,\left(^{*}\right)$ indicates significance $(\mathrm{p}<0.05)$ when compared to the control concentration of $0 \mu \mathrm{M}$. Concentrations of 15 to $20 \mu \mathrm{M}$ show a significant increase in luciferase reporter levels. Results from one-way ANOVA show significant increases between means of concentrations. (UNT $=$ untransfected $)$. 


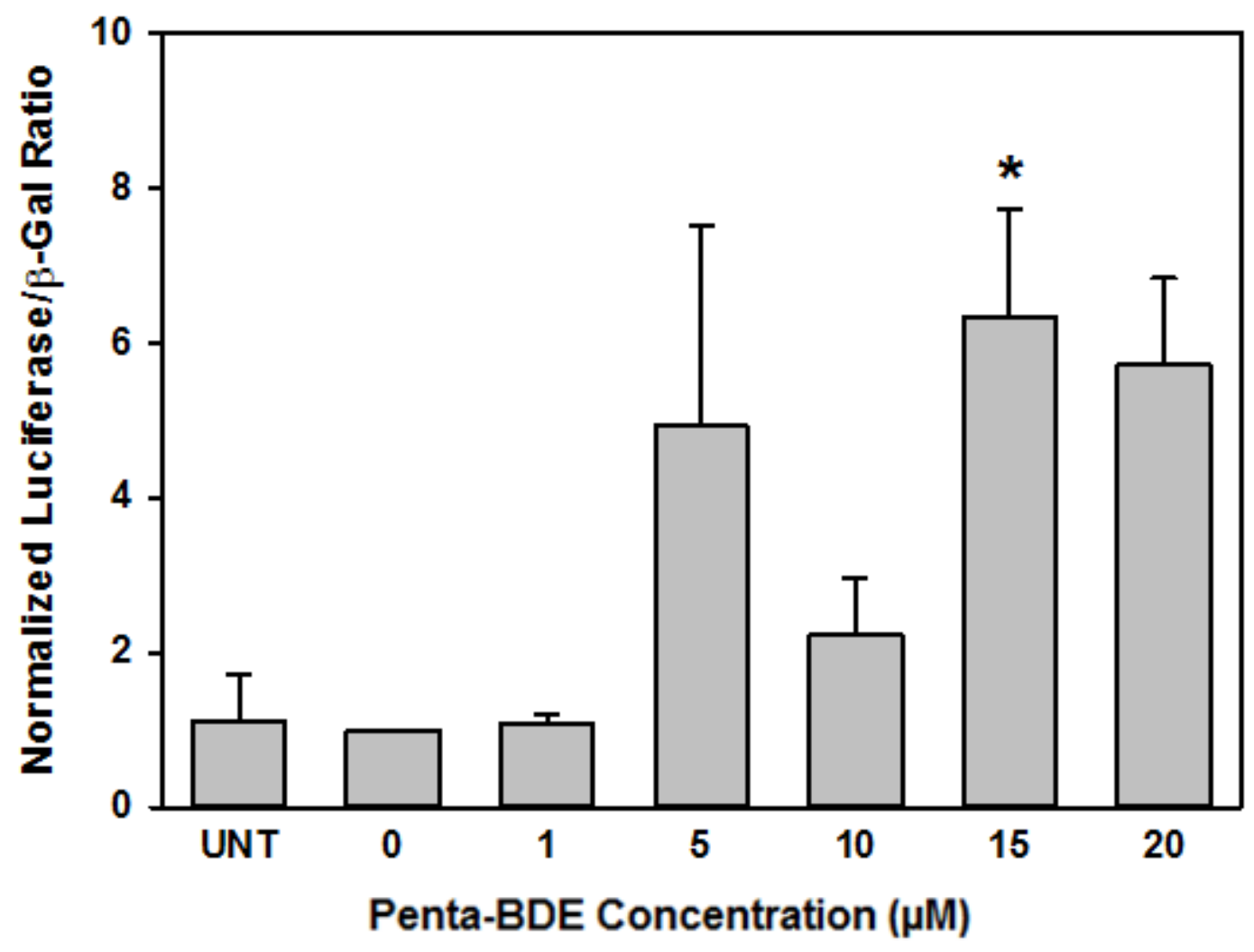

Figure 14: Luciferase reporter assay of HEK293T cells treated with penta-BDE. Results show an increase ARE/ EpRE transcription levels with increasing chemical concentrations. This means that the proteins Nrf1 and Nrf2 have an increase in activity level with an increase in chemical treatment. When the cell experiences greater levels of oxidative stress, it will kick start the antioxidant response pathway via Nrfl-ARE and Nrf2-ARE. Values shown are the means normalized to the control $(0 \mu \mathrm{M}) \pm \mathrm{SEM}$. $\mathrm{N}=3$, $\left(^{*}\right)$ indicates significance $(\mathrm{p}<0.05)$ when compared to the control concentration of $0 \mu \mathrm{M}$. The second highest concentration, $15 \mu \mathrm{M}$, was the only data point that showed a significant increase in luciferase reporter levels. Results from one-way ANOVA show significant decreases between means of concentrations. (UNT $=$ untransfected). 


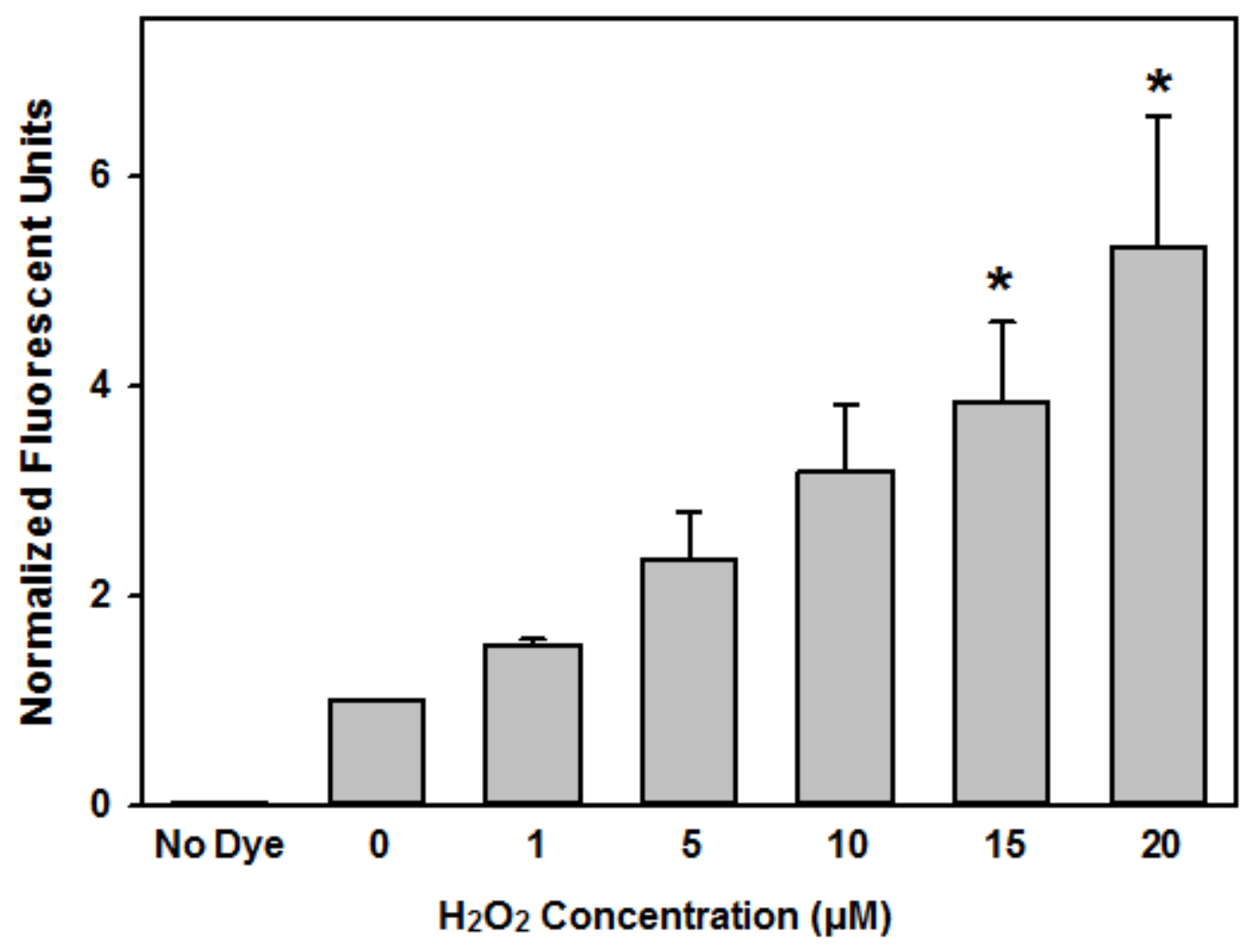

Figure 15: Activity level of beta-galactosidase enzyme in $\mathrm{HEK293T}$ cells after $\mathrm{H}_{2} \mathrm{O}_{2}$ treatment. As hydrogen peroxide concentration increases (after 2 hour treatments), so does the activity of the beta-galactosidase enzyme. Values shown are the means normalized to the control $(0 \mu \mathrm{M}) \pm$ SEM. $N=3,\left(^{*}\right)$ indicates significance $(\mathrm{p}<0.05)$ when compared to the control concentration of $0 \mu \mathrm{M}$. Concentrations of 15 to $20 \mu \mathrm{M}$ show a significant increase in enzyme activity levels. Results from one-way ANOVA show significant increases between means of concentrations. 


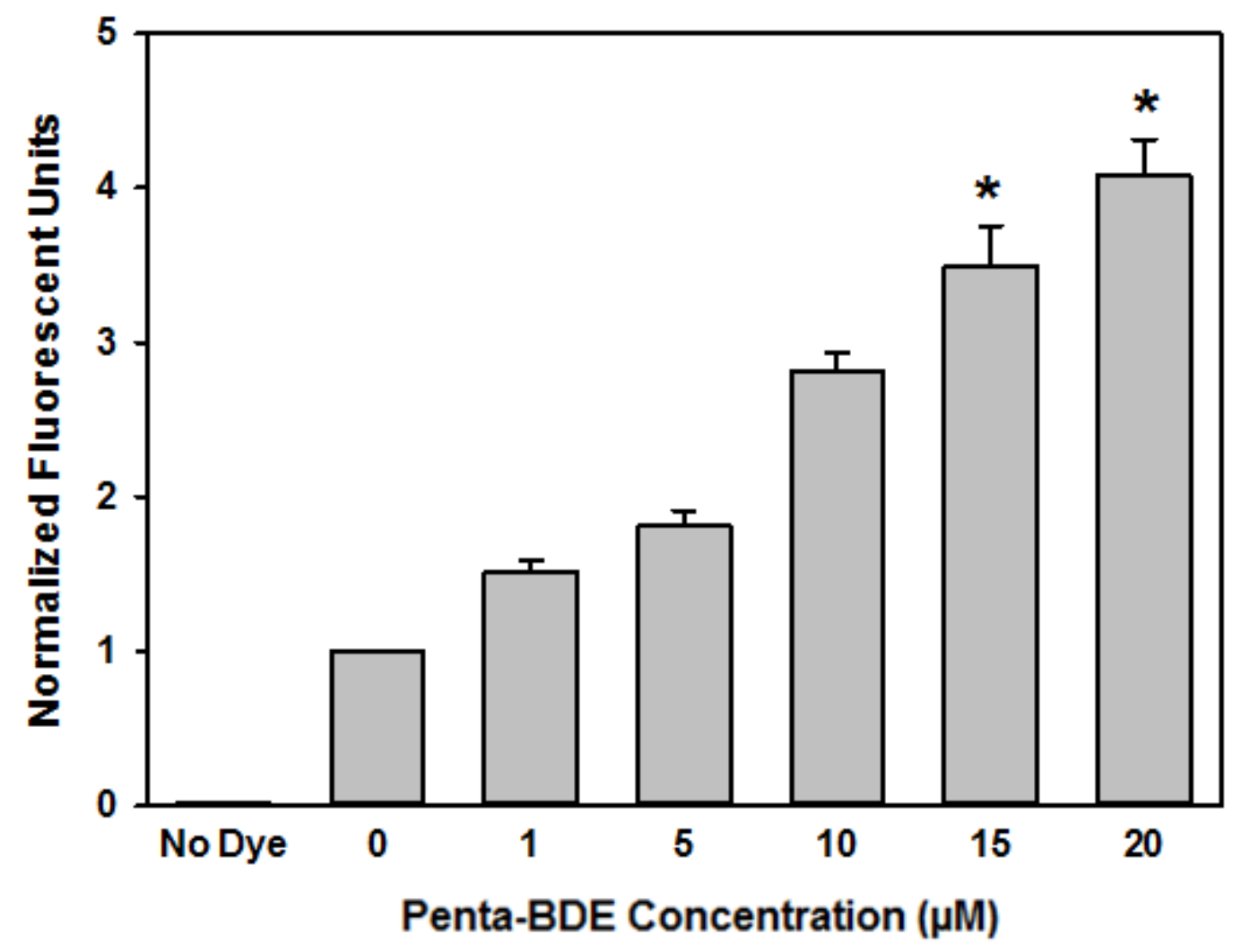

Figure 16: Activity level of beta-galactosidase enzyme in HEK293T cells after pentaBDE treatment. As penta-BDE concentration increases (after 24 hour treatments), so does the activity of the beta-galactosidase enzyme. Values shown are the means normalized to the control $(0 \mu \mathrm{M}) \pm$ SEM. $N=3,(*)$ indicates significance $(\mathrm{p}<0.05)$ when compared to the control concentration of $0 \mu \mathrm{M}$. Concentrations of 15 to $20 \mu \mathrm{M}$ show a significant increase in enzyme activity levels. Results from one-way ANOVA show significant increases between means of concentrations. 


\section{Chapter 4: Discussion}

\section{1: Hydrogen Peroxide Is A Strong Pro-oxidant That Increases Nrf1 and Nrf2 Protein Levels}

To show the possible effects of oxidative stress caused by PBDEs, we first used a well-known pro-oxidant, hydrogen peroxide, as a positive control in order to compare results between the two chemicals. Hydrogen peroxide is highly reactive and excessive amounts can cause oxidative stress by creating ROS and oxidizing proteins (Oliver \& Brooke, 2016). It has been shown that hydrogen peroxide induces oxidative stress in cultured bovine mammary epithelial cells and results in reduced cell growth (Jin et al., 2016).

The cellular response to oxidative stress is to activate transcription factors that control the expression of antioxidant and phase two enzymes. The transcription factors Nrf1 and Nrf2 are best known to regulate antioxidant and detoxification enzyme expression through AREs/EpREs and the protein levels of both factors increased with increased hydrogen peroxide treatment (Figure 7b). This revealed that HEK293 cells are capable of inducing both of these factors in response to oxidative stress.

\section{2: Penta-Brominated Diphenyl Ether (penta-DBE) Treatment Increases Nrf1 and}

\section{Nrf2 Protein Levels}

Experiments were repeated with penta-DBE as the chemical of choice $\left(\mathrm{C}_{12} \mathrm{H}_{5} \mathrm{Br}_{5} \mathrm{O}\right)$, and similar results were observed. With increasing PDBE concentration, Nrf1 and Nrf2 protein levels also increase (Figure 8b). As similar results were obtained 
from both $\mathrm{H}_{2} \mathrm{O}_{2}$ and penta-BDE chemical treatments, this suggested that PBDEs are also pro-oxidants.

Studies have shown PBDEs cause oxidative stress when their metabolites react with cellular molecules to produce ROS in excess of what the cell's defenses can neutralize, leading to a shift in redox homeostasis and causing large amounts of cellular damage (Lefevre et al., 2015). Researchers found that the genes encoding for two antioxidant enzymes, Cat and Sodl had decreased expression levels in the ovaries of female mice exposed to high levels of PBDEs (Lefevre et al., 2015). These treatments lasted two to four weeks, according to the study, and thus prolonged exposure to PBDEs was found to cause the impairment of the antioxidant response. Schang and colleagues showed that the metabolism of organophosphate flame retardants is very similar to that of PBDEs, in that both produce ROS, which drives the cell towards apoptosis (Schang et al., 2016). In their studies, increased levels of lipid peroxidation with chemical treatment contributed to the cytotoxicity (Schang et al., 2016).

Our study examined the effects of acute exposure to PDBEs with a maximum treatment time of 24 hours. The results show an increased antioxidant response with a subsequent decrease in antioxidant response with prolonged treatment times. When the cell is faced with acute stress, it is able to respond and elicit the activity of Nrf1 and Nrf2 in order to activate production of antioxidant and phase 2 enzymes. With chronic exposure to PBDEs, the cell's ability to respond to oxidative stress is reduced. PBDEs are present in household material, such as insulation, textiles, building materials, plastics, electronics, and foams (Frouin, et al., 2010). Over time, their break down products cause long-term exposure to PDBE metabolites in humans. 


\section{3: Protein Carbonyl Group Production and Aging}

Following a very simple procedure, we attempted to show that the oxidative stress produced by PDBEs contribute to the cellular aging process (as predicted by the Free Radical Theory of Aging), by measuring carbonyl groups on cellular proteins. Carbonyl groups are formed on oxidatively modified proteins and have been used as an indicator of cellular aging (Sohal et al., 2002). Both hydrogen peroxide and PBDE treatments caused an increase in the concentration of protein carbonyls groups, with a statistically significant difference between the controls $(0 \mu \mathrm{M}$ of chemical $)$ and the highest concentration of chemicals $(20 \mu \mathrm{M})$ (Figures 9 and 10 respectively).

Our results show that there is a significant amount of oxidized proteins produced in the highest treatment level of penta-BDE. Therefore, the cell is experiencing oxidative stress causing damage to proteins. Because our study was acute, we cannot tell if the damaged proteins would be cleared by the cell, or if they will cause excessive loss of function and cause the cell to die. This is one limitation encountered in this study, where other studies observed cellular senescence with long term chemical exposure. Prolonged oxidative damage and excessive loss of protein function due to oxidation has been the onset of the aging process in other studies (Smith et al., 1991; Stadtman, 2006; Stadtman \& Berlett, 1997).

Though short-term exposure studies, such as this one, show effects from a single snap shot in time, there are still dose-dependent effects being observed. The increasing concentrations from 0 to $20 \mu \mathrm{M}$ show an increase in the amount of carbonyl groups, showing a dose-related trend. This means that the more chemical cells are exposed to, the more protein carbonyl groups are formed. 


\section{4: Lipid Oxidation and Aging}

To further connect oxidative stress generated by PDBEs to aging, we examined phospholipids oxidation after chemical treatment. Cells exposed to increased concentrations of both hydrogen peroxide and PDBEs had increased concentration of 8isoprostane (also known as 8-iso prostaglandin $\mathrm{F}_{2 \alpha}$ ) (Figures 11 and 12 respectively). The presence of oxidized phospholipids in our studies suggested that chemical treatment times and concentrations were sufficient enough to produce oxidative damage to biomolecules. This phospholipid is a potent renal vasoconstrictor and has been implicated as a mediator of oxidative stress-derived toxicity (Banerjee et al., 1992). Therefore, since the trend shows an increase in 8-isoprostane, the effects implied are those of extensive oxidative stress from increasing chemical concentrations (Vacchiano \& Tempel, 1994). Other studies have also shown that 8-isoprostane tends to increase with the age of the subject (Wang et al., 1995).

Our results show a significant amount of oxidized lipids produced in the highest treatment level of penta-BDE. Therefore, the cell is experiencing oxidative stress causing the production of ROS that go on to react with lipids and cause oxidative damage. Due to the short time duration of treatments in this study, it could not be determined if the accrued lipid damage was cleared from or repaired by the cell or not. Prolonged oxidative damage and excessive loss of important biomolecules that are energy sources for the cell (Cooper, 2000), can cause the cell to deteriorate and die. Even though our study was short term, the chemical treatments still caused an effect similar to long-term exposure to other oxidizing agents. 


\section{5: Activation of the AREs/EpREs by Penta-BDE}

To further support evidence that PDBEs generate oxidative stress, we measured Nrf1 and Nrf2 protein and activity levels. To do this, we used an ARE-luciferase reporter which contained three ARE/EpRE binding sequences from the GCLC promoter (Brasier et al., 1988). The activity and protein levels of both Nrf1 and Nrf2 increased with both $\mathrm{H}_{2} \mathrm{O}_{2}$ and penta-BDE treatments (Figures 13 and 14). Nrf2 is a well-known regulator of antioxidant and cellular protective genes, (Chepelev et al., 2013b), and likewise, Nrfl is important for cell survival when the cell is under oxidative stress (Kwong et al., 1999). Both Nrf1 and Nrf2 protein levels increased with increasing treatment concentration (Figures $7 \mathrm{~b}$ and $8 \mathrm{~b}$ respectively). As well as their binding to the AREs/EpREs, cell treatment with PDBEs resulted in an increase in the content of the Nrf proteins within the cell (Figures 8a and 8b). It can therefore be concluded that PBDEs induce Nrf1 and Nrf2 activity in the antioxidant response to oxidative stress.

The time of treatments utilized in this study ( 2 hours and 24 hours) may be considered to have placed the cell under acute stress as HEK293T cells were able to elicit an antioxidant response and to recover from the treatments. More prolonged or chronic exposure to PDBEs may cause excessive build-up of oxidatively damaged proteins, which may compromise cellular function and direct the cell towards autophagy, apoptosis or cellular aging and senescence.

\section{6: Senescence-associated beta-galactosidase (SA- $\beta$-gal) activity increases with $\mathrm{H}_{2} \mathrm{O}_{2}$ and penta-BDE exposure}


As seen from the results (Figures 15 and 16), as treatment concentration increased (either $\mathrm{H}_{2} \mathrm{O}_{2}$ or PDBEs), so did the number of fluorescent cells. These results show that intracellular levels of $\beta$-galactosidase enzyme increased due to chemical treatment, allowing more substrate to be converted into fluorescent product. Aging cells, and cells with the potential to differentiate and mature, tend to express higher levels of betagalactosidase activity, a trend that has been termed senescence-associated betagalactosidase activity (SA- $\beta$-gal) (Dimri et al., 1995; Beattie et al., 1994). Therefore, we have shown that the highest concentrations of PDBEs used in the experiments in this study causes cells to produce more $\beta$-galactosidase enzyme activity and breakdown the $\mathrm{C}_{12} \mathrm{FDG}$ substrate, an indication that they experiencing a similar effect to that of a cell that is undergoing senescence.

The flow cytometry utilized in this study was developed for the detection of $\beta$ galactosidase activity in single cells (Miao et al., 1993). The fluorogenic substrate, $\mathrm{C}_{12} \mathrm{FDG}$ (5-dodecanoylamino-fluorescein di- $\beta$-D-galactopyranoside), contains a lipophilic group, allowing it to cross the cell membrane (Miao et al., 1993). When this substrate is hydrolyzed by intracellular $\beta$-galactosidase, it produces a green fluorescent product that is retained in the cell. In turn, the positively stained cells display fluorescence, which is measured by flow cytometry (Miao et al., 1993). The activity of $\beta$ galactosidase increases with aging in cell lines and the assay for its activity is a common measure of cellular senescence (Miao et al., 1993). This assay is a novel way of examining cell senescence response to chemical exposure and has only been utilized in a few other studies (Behnia et al., 2015). Due to its novelty, the use of this assay is in itself a limitation, since there is little literature to support the findings. 


\section{Chapter 5: Conclusion and Future Direction}

In conclusion, we believe that this Master's Thesis was able to demonstrate that PDBEs cause oxidative stress to a human embryonic kidney cell. Furthermore, such oxidative stress increases the activity of the senescence-associated $\beta$-galactosidase. We used $\mathrm{H}_{2} \mathrm{O}_{2}$ as our positive pro-oxidant control and compared the results of BDE to that of $\mathrm{H}_{2} \mathrm{O}_{2}$, to see if PBDE produces similar effects.

HEK293T cells responded, in a similar manner to both $\mathrm{H}_{2} \mathrm{O}_{2}$ and PBDE, in the following ways: (1) cells produced more of the antioxidant gene regulating proteins $\mathrm{Nrfl}$ and Nrf2 (Figures 7 and 9), (2) cells increased the activity levels of antioxidant gene regulating proteins $\mathrm{Nrfl}$ and $\mathrm{Nrf} 2$ (Figures 15 and 16), (3) cells accumulated oxidized biomolecules, specifically proteins and lipids (Figures 11 to 14), and (4) cells produced more $\beta$-galactosidase enzyme, a well-known biomarker of cellular senescence (Figures 17 and 18).

Evidence shows that cells tend to age when faced with prolonged and extensive oxidative stress and impaired antioxidant response mechanisms (Finkel \& Holbrook, 2000). With our experiments having a maximum treatment time of only 24 hours, the cell still produced effects from chemical treatment. The PDBE concentrations used in our experiments (maximum of $20 \mu \mathrm{M}$ ) were comparable to ranges of $\mathrm{H}_{2} \mathrm{O}_{2}$ concentrations (100 $\mu \mathrm{M}$ with endothelial cells; Coyle \& Kader, 2007 and $1000 \mu \mathrm{M}$ with epithelial cells; Jin et al., 2016), and PBDE concentrations (12 $\mu \mathrm{M}$ with immune cells; Frouin et al., 2010 and $30 \mu \mathrm{M}$ with neuroblastoma cells; Tagliaferri et al., 2010) used in other studies. Shortterm treatment (24 hours or less) of human cells with PBDE was sufficient to produce markers of oxidative stress in this study. 
Though this study has its limitations, it is new and provides insight on the cellular response with exposure to flame retardants used in homes and many consumer products. Specifically, we show that penta-BDE produces the biomarkers of oxidative stress and cellular senescence. These findings are novel to this study, and though future studies are needed for further support, this study provides a starting point for future researches.

Future studies should focus on prolonged chemical exposure, with or without recovery periods, since it is prolonged exposure to oxidative stress that results in cellular senescence. These results provide supplementary evidence that PDBEs cause oxidative stress which leads to an increase in the markers of cell senescence. Furthermore, studies with PDBEs using models that do not age, such as cancer cells, can provide additional evidence into the chemical's potential to induce marker enzymes of cell senescence. Also looking at animals models to compare in vitro to in vivo results will provide more incite onto how these chemicals are metabolized and distributed throughout the body. Lastly, cells originating from different tissues should be tested to determine if all of the tissues respond in a similar manner. For example, studies have shown that PBDEs cause neurotoxic effects (Tagliaferri et al., 2010), and therefore performing such tests in neuronal cells can show if neurons are more or less sensitive to such effects. 


\section{Chapter 6: References}

Abdelouahab, N., Ainmelk, Y., \& Takser, L. (2011). Polybrominated diphenyl ethers and sperm quality. Reproductive Toxicology, 31(4), 546-550.

Adachi, H., Fujiwara, Y., \& Ishii, N. (1998). Effects of oxygen on protein carbonyl and aging in Caenorhabditis elegans mutants with long (age-1) and short (mev-1) life spans. The Journals Of Gerontology Series A: Biological Sciences And Medical Sciences, 53(4), B240-B244.

ATSDR (Agency for Toxic Substances and Disease Registry). (2004). Toxicological profile for polybrominated biphenyl and polybrominated diphenyl ethers. U.S. Department of Health and Human Services, Public Health Service, Atlanta Georgia, September, 2004.

Banerjee, M., Kang, K. H., Morrow, J. D., Roberts, L. J., \& Newman, J. H. (1992). Effects of a novel prostaglandin, 8-epi-PGF2 alpha, in rabbit lung in situ. American Journal Of Physiology-Heart And Circulatory Physiology, 263(3), H660-H663.

Beattie, G. M., Levine, F., Mally, M. I., Otonkoski, T., O’Brien, J. S., Salomon, D. R., \& Hayek, A. (1994). Acid beta-galactosidase: a developmentally regulated marker of endocrine cell precursors in the human fetal pancreas. Journal Of Clinical Endocrinology And Metabolism, 78(5), 1232-1240. 
Beckman, K. B., \& Ames, B. N. (1998). The free radical theory of aging matures. Physiological Reviews, 78(2), 547-581.

Behnia, F., Peltier, M. R., Saade, G. R., \& Menon, R. (2015). Environmental pollutant polybrominated diphenyl ether, a flame retardant, induces primary amnion cell senescence. American Journal Of Reproductive Immunology, 74(5), 398-406.

Berlett, B. S. \& Stadtman, E. R. (1997). Protein oxidation in aging, disease, and oxidative stress. Journal Of Biological Chemistry, 272, 20313-20316.

Brasier, A. R., Tate, J. E., \& Habener, J. F. (1988). Optimized use of the firefly luciferase assay as a reporter gene in mammalian cell lines. Biotechniques, 7(10), 1116-1122.

Bugno, M., Daniel, M., Chepelev, N. L., \& Willmore, W. G. (2015). Changing gears in Nrf1 research, from mechanisms of regulation to its role in disease and prevention. Biochimica Et Biophysica Acta (BBA)-Gene Regulatory Mechanisms, 1849(10), 12601276.

Cadenas, E., \& Davies, K. J. (2000). Mitochondrial free radical generation, oxidative stress, and aging. Free Radical Biology And Medicine, 29(3), 222-230.

Carey, J. R., Liedo, P., Müller, H. G., Wang, J. L., \& Vaupel, J. W. (1998). Dual modes of aging in Mediterranean fruit fly females. Science, 281(5379), 996-998. 
Chemicals Management Division (CMD), Environment Canada. (2015). Polybrominated Diphenyl Ethers (PBDEs). https://www.ec.gc.ca/toxiquestoxics/Default.asp?lang=En\&n=98E80CC6-1\&xml=5046470B-2D3C-48B4-9E46735B7820A444.

Chepelev, N. L., \& Willmore, W. G. (2011a). Regulation of iron pathways in response to hypoxia. Free Radical Biology And Medicine, 50(6), 645-66.

Chepelev, N. L., Bennitz, J. D., Huang, T., McBride, S., \& Willmore, W. G. (2011b). The Nrf1 CNC-bZIP protein is regulated by the proteasome and activated by hypoxia. PloS ONE, 6(12): e29167.

Chepelev, N. L., Enikanolaiye, M. I., Chepelev, L. L., Almohaisen, A., Chen, Q., Scoggan, K. A., Coughlan, M.C., Cao, X.L., Jin, X., \& Willmore, W. G. (2013a). Bisphenol A activates the Nrfl/2-antioxidant response element pathway in HEK 293 cells. Chemical Research In Toxicology, 26(3), 498-506.

Chepelev, N.L., Zhang, H., Liu, H., McBride, S., Seal, A.J., Morgan, T.E., Finch, C.E., Willmore, W.G., Davies, K.J., \& Forman, H.J. (2013b). Competition of nuclear factorerythroid 2 factors related transcription factor isoforms, Nrf1 and Nrf2, in antioxidant enzyme induction. Redox Biology, 1(1), 183-189.

Cooper, G. M. (2000). The Cell: A Molecular Approach. 2nd edition. Sunderland (MA): 
Sinauer Associates. The Molecular Composition of Cells. Available from: http://www.ncbi.nlm.nih.gov/books/NBK9879/.

Cosgrove, M. S., Bever, K., Avalos, J. L., Muhammad, S., Zhang, X., \& Wolberger, C. (2006). The structural basis of sirtuin substrate affinity. Biochemistry, 45(24), 7511-7521.

Costa, L. G., Giordano, G., Tagliaferri, S., Caglieri, A., \& Mutti, A. (2008). Polybrominated diphenyl ether (PBDE) flame retardants: environmental contamination, human body burden and potential adverse health effects. ACTA Biomedica, 79(3), 172183.

Coyle, C. H., \& Kader, K. N. (2007). Mechanisms of $\mathrm{H}_{2} \mathrm{O}_{2}$-induced oxidative stress in endothelial cells exposed to physiologic shear stress. ASAIO Journal, 53(1), 17-22.

Dalle-Donne, I., Rossi, R., Giustarini, D., Milzani, A., \& Colombo, R. (2003). Protein carbonyl groups as biomarkers of oxidative stress. Clinica Chimica ACTA, 329(1), 23-38.

Darnerud, P. O. (2008). Brominated flame retardants as possible endocrine disrupters. International Journal Of Andrology, 31(2), 152-160.

Dassanayake, R. P. S., Wei, H., Chen, R. C., \& Li, A. (2009). Optimization of the matrix solid phase dispersion extraction procedure for the analysis of polybrominated diphenyl ethers in human placenta. Analytical Chemistry, 81(23), 9795-9801. 
Davies, K. J. (1995). Oxidative stress, the paradox of aerobic life. Biochemical Society Symposia, 61, 1-31.

Debacq-Chainiaux, F., Erusalimsky, J. D., Campisi, J., \& Toussaint, O. (2009). Protocols to detect senescence-associated beta-galactosidase (SA- $\beta$ gal) activity, a biomarker of senescent cells in culture and in vivo. Nature Protocols, 4(12), 1798-1806.

Dimri, G. P., Lee, X., Basile, G., Acosta, M., Scott, G., Roskelley, C., Medrano, E. E., Linskensi, M., Rubeljii, I., Pereira-Smith, O., Peacocke, M., \& Campisi, J. (1995). A biomarker that identifies senescent human cells in culture and in aging skin in vivo. Proceedings Of The National Academy Of Sciences, 92(20), 9363-9367.

D’Orazio, J., Jarrett, S., Amaro-Ortiz, A., \& Scott, T. (2013). UV radiation and the skin. International Journal Of Molecular Sciences, 14(6), 12222-12248.

Ema, M., Fujii, S., Hirata-Koizumi, M., \& Matsumoto, M. (2008). Two-generation reproductive toxicity study of the flame retardant hexabromocyclododecane in rats. Reproductive Toxicology, 25(3), 335-351.

Finkel, T., \& Holbrook, N. J. (2000). Oxidants, oxidative stress and the biology of aging. Nature, 408, 239-247. 
Frederiksen, M., Thomsen, M., Vorkamp, K., \& Knudsen, L. E. (2009). Patterns and concentration levels of polybrominated diphenyl ethers (PBDEs) in placental tissue of women in Denmark. Chemosphere, 76(11), 1464-1469.

Frouin, H., Lebeuf, M., Hammill, M., Masson, S., \& Fournier, M. (2010). Effects of individual polybrominated diphenyl ether (PBDE) congeners on harbour seal immune cells in vitro. Marine Pollution Bulletin, 60(2), 291-298.

Gibbons, J. W. (1987). Why do turtles live so long? BioScience, 37(4), 262-269.

Gomara, B., Herrero, L., Ramos, J. J., Mateo, J. R., Fernandez, M. A., Garcia, J. F., \& Gonzalez, M. J. (2007). Distribution of polybrominated diphenyl ethers in human umbilical cord serum, paternal serum, maternal serum, placentas, and breast milk from Madrid population, Spain. Environmental Science And Technology, 41(20), 6961-6968.

Hall, B. M., Balan, V., Gleiberman, A. S., Strom, E., Krasnov, P., Virtuoso, L. P., Rydkina, E., Vujcic, S., Balan, K., Gitlin, I., Leonova, K., Polinsky, A., Chernova, O. B., \& Gudkov, A. V. (2016). Aging of mice is associated with p16 (Ink4a)-and $\beta$ galactosidase-positive macrophage accumulation that can be induced in young mice by senescent cells. Aging (Albany NY), 8(7), 1294.

Harley, K. G., Marks, A. R., Chevrier, J., Bradman, A., Sjödin, A., \& Eskenazi, B. (2010). PBDE concentrations in women's serum and fecundability. Environmental Health 
Perspectives, 118(5), 699.

Jervis, K. M., \& Robaire, B. (2004). The Effects of Long Term Vitamin E Treatment on Gene Expression and Oxidative Stress Damage in the Aging Brown Norway Rat Epididymis. Biology Of Reproduction, 71(4), 1088-1095.

Ji, K., Choi, K., Giesy, J. P., Musarrat, J., \& Takeda, S. (2011). Genotoxicity of several polybrominated diphenyl ethers (PBDEs) and hydroxylated PBDEs, and their mechanisms of toxicity. Environmental Science And Technology, 45(11), 5003-5008.

Jin, X., Wang, K., Liu, H., Hu, F., Zhao, F., \& Liu, J. (2016). Protection of bovine mammary epithelial cells from hydrogen peroxide-induced oxidative cell damage by resveratrol. Oxidative Medicine And Cellular Longevity, 2016.

Johnson, P. I., Altshul, L., Cramer, D. W., Missmer, S. A., Hauser, R., \& Meeker, J. D. (2012). Serum and follicular fluid concentrations of polybrominated diphenyl ethers and in-vitro fertilization outcome. Environment International, 45, 9-14.

Johnson, P. I., Stapleton, H. M., Mukherjee, B., Hauser, R., \& Meeker, J. D. (2013). Associations between brominated flame retardants in house dust and hormone levels in men. Science Of The Total Environment, 445, 177-184.

Jung, K-A, \& Kwak, M-K. (2010). The Nrf2 System as a potential target for the 
development of indirect antioxidants. Molecules (Basel, Switzerland). 15(10), 7266-7291.

Kaneuchi T., Togawa T., Matsuo T., Fuyama Y., Aigaki T. (2003). Efficient measurement of $\mathrm{H}_{2} \mathrm{O}_{2}$ resistance in Drosophila using an activity monitor. Biogerontology 4: $157-165$.

Kavsan, V. M., Iershov, A. V., \& Balynska, O. V. (2011). Immortalized cells and one oncogene in malignant transformation: old insights on new explanation. BioMed Central Cell Biology, 12(1), 23-24.

Kawai, Y., Garduno, L., Theodore, M., Yang, J., \& Arinze, I. J. (2011). Acetylationdeacetylation of the transcription factor Nrf2 (nuclear factor erythroid 2-related factor 2) regulates its transcriptional activity and nucleocytoplasmic localization. Journal of Biological Chemistry, 286(9), 7629-7640.

Kim, Y. R., Harden, F. A., Toms, L. M. L., \& Norman, R. E. (2014). Health consequences of exposure to brominated flame retardants: a systematic review. Chemosphere, 106, 1-19.

Kwong, M., Kan, Y. W., \& Chan, J. Y. (1999). The CNC basic leucine zipper factor, Nrf1, is essential for cell survival in response to oxidative stress-inducing agents. Journal Of Biological Chemistry, 274, 37491-37498. 
Langston, J. W., Forno, L. S., Tetrud, J., Reeves, A. G., Kaplan, J. A., \& Karluk, D. (1999). Evidence of active nerve cell degeneration in the substantia nigra of humans years after 1-methyl-4-phenyl-1, 2, 3, 6-tetrahydropyridine exposure. Annals Of Neurology, 46(4), 598-605.

Lefevre, P. L., Berger, R. G., Ernest, S. R., Gaertner, D. W., Rawn, D. F., Wade, M. G., Robaire, B., \& Hales, B. F. (2015). Exposure of female rats to an environmentallyrelevant mixture of brominated flame retardants targets the ovary, affecting folliculogenesis and steroidogenesis. Biology Of Reproduction, biolreprod-115.

Legler, J. (2008). New insights into the endocrine disrupting effects of brominated flame retardants. Chemosphere, 73(2), 216-222.

Letcher, R. J., Marteinson, S. C., \& Fernie, K. J. (2014). Dietary exposure of American kestrels (Falco sparverius) to decabromodiphenyl ether (BDE-209) flame retardant: uptake, distribution, debromination and cytochrome P450 enzyme induction. Environment International, 63, 182-190.

Lewington, A., \& Parker, E. (1999). Ancient trees: trees that live for 1000 years. Collins \& Brown.

Ma, J., Qiu, X., Ren, A., Jin, L., \& Zhu, T. (2012). Using placenta to evaluate the polychlorinated biphenyls (PCBs) and polybrominated diphenyl ethers (PBDEs) exposure 
of fetus in a region with high prevalence of neural tube defects. Ecotoxicology And Environmental Safety, 86, 141-146.

McDonald, T. A. (2002). A perspective on the potential health risks of PBDEs. Chemosphere, 46(5), 745-755.

Meeker, J. D., \& Stapleton, H. M. (2010). House dust concentrations of organophosphate flame retardants in relation to hormone levels and semen quality parameters. Environmental Health Perspectives, 118(3), 318.

Miao, F., Todd, P., \& Kompala, D. S. (1993). A single-cell assay of $\beta$-galactosidase in recombinant Escherichia coli using flow cytometry. Biotechnology And Bioengineering, 42(6), 708-715.

Mulcahy, R. T., Wartman, M. A., Bailey, H. H., \& Gipp, J. J. (1997). Constitutive and $\beta$ naphthoflavone-induced expression of the human $\gamma$-glutamylcysteine synthetase heavy subunit gene is regulated by a distal antioxidant response element/TRE sequence. Journal Of Biological Chemistry, 272(11), 7445-7454.

Noppe, G., Dekker, P., de Koning-Treurniet, C., Blom, J., van Heemst, D., Dirks, R. W., Tanke, H. J., Westendorp, R. G. J., \& Maier, A. B. (2009). Rapid flow cytometric method for measuring senescence associated $\beta$-galactosidase activity in human fibroblasts. Cytometry Part A, 75(11), 910-916. 
Oliver, S. V., \& Brooke, B. D. (2016). The role of oxidative stress in the longevity and insecticide resistance phenotype of the major malaria vectors Anopheles arabiensis and Anopheles funestus. PloS ONE, 11(3), e0151049.

Olovnikov, A. M. (2003). The redusome hypothesis of aging and the control of biological time during individual development. Biochemistry (Moscow), 68(1), 2-33.

Pacifici, R. E., \& Davies, K. J. A. (1991). Protein, lipid and DNA repair systems in oxidative stress: the free-radical theory of aging revisited. Gerontology, 37(1-3), 166-180.

Parhami, F. (2003). Possible role of oxidized lipids in osteoporosis: could hyperlipidemia be a risk factor? Prostaglandins, Leukotrienes And Essential Fatty Acids, 68(6), 373-378.

Reznick, A. Z., \& Packer, L. (1994). Oxidative damage to proteins: spectrophotometric method for carbonyl assay. Methods In Enzymology, 233: 357-363.

Saltsman, K. (2005). Chapter 5: The Last Chapter: Cell Aging and Death. In Inside The Cell (pp. 60-72). Bethesda, MD: NIH Publication No. 05-1051.

Scandalios, J. G. (1993). Oxygen stress and superoxide dismutases. Plant Physiology, 101(1), 7 .

Schang, G., Robaire, B., \& Hales, B. F. (2016). Organophosphate flame retardants act as 
endocrine-disrupting chemicals in MA-10 mouse tumor Leydig cells. Toxicological Sciences, 150(2), 499-509.

Shih, Y. H., \& Wang, C. K. (2009). Photolytic degradation of polybromodiphenyl ethers under UV-lamp and solar irradiations. Journal Of Hazardous Materials, 165(1), 34-38.

Smith, C. D., Carney, J. M., Starke-Reed, P. E., Oliver, C. N., Stadtman, E. R., Floyd, R. A., \& Markesbery, W. R. (1991). Excess brain protein oxidation and enzyme dysfunction in normal aging and in Alzheimer disease. Proceedings Of The National Academy Of Sciences, 88(23), 10540-10543.

Sohal, R. S. \& Weindruch, R. (1996). Oxidative stress, caloric restriction, and aging. Science, 273, 59-63.

Sohal, R. S., Mockett, R. J., \& Orr, W.C. (2002). Mechanisms of aging: an appraisal of the oxidative stress hypothesis. Free Radical Biology And Medicine, 33, 575-586.

Stadtman, E. R. (1992). Protein oxidation and aging. Science, 257, 1220-1224.

Stadtman, E. R. \& Levine, R. L. (2000). Protein oxidation. Annals Of The New York Academy Of Sciences, 899, 191-208.

Stadtman, E. R. (2006). Protein oxidation and aging. Free Radical Research, 40(12), 
$1250-1258$.

Stadtman, E. R., \& Berlett, B. S. (1997). Reactive oxygen-mediated protein oxidation in aging and disease. Chemical Research In Toxicology, 10(5), 485-494.

Stapleton, H. M., Letcher, R. J., \& Baker, J. E. (2004). Debromination of polybrominated diphenyl ether congeners BDE 99 and BDE 183 in the intestinal tract of the common carp (Cyprinus carpio). Environmental Science And Technology, 38(4), 1054-1061.

Tagliaferri, S., Caglieri, A., Goldoni, M., Pinelli, S., Alinovi, R., Poli, D., Pellacani, C., Giordano, G., Mutti, A., \& Costa, L. G. (2010). Low concentrations of the brominated flame retardants BDE-47 and BDE-99 induce synergistic oxidative stress-mediated neurotoxicity in human neuroblastoma cells. Toxicology In Vitro, 24(1), 116-122.

Tanase, M., Urbanska, A. M., Zolla, V., Clement, C. C., Huang, L., Morozova, K., Follo, C., Goldberg, M., Roda, B., Reschiglian, P. \& Santambrogio, L. (2016). Role of carbonyl modifications on aging-associated protein aggregation. Scientific Reports, 6, 19311.

Thimmulappa, R. K., Mai, K. H., Srisuma, S., Kensler, T. W., Yamamoto, M., \& Biswal, S. (2002). Identification of Nrf2-regulated genes induced by the chemopreventive agent sulforaphane by oligonucleotide microarray. Cancer Research, 62(18), 5196-5203.

Thomas, P., \& Smart, T. G. (2005). HEK293 cell line: a vehicle for the expression of 
recombinant proteins. Journal Of Pharmacological And Toxicological Methods, 51(3), $187-200$.

Tosato, M., Zamboni, V., Ferrini, A., \& Cesari, M. (2007). The aging process and potential interventions to extend life expectancy. Clinical Interventions In Aging, 2(3), 401-412.

Turyk, M. E., Persky, V. W., Imm, P., Knobeloch, L., Chatterton Jr, R., \& Anderson, H. A. (2008). Hormone disruption by PBDEs in adult male sport fish consumers. Environmental Health Perspectives, 116(12), 1635.

Vacchiano, C. A., \& Tempel, G. E. (1994). Role of nonenzymatically generated prostanoid, 8-iso-PGF2 alpha, in pulmonary oxygen toxicity. Journal Of Applied Physiology, 77(6), 2912-2917.

Valavanidis, A., Vlahogianni, T., Dassenakis, M., \& Scoullos, M. (2006). Molecular biomarkers of oxidative stress in aquatic organisms in relation to toxic environmental pollutants. Ecotoxicology And Environmental Safety, 64(2), 178-189.

van der Ven, L. T., van de Kuil, T., Leonards, P. E., Slob, W., Lilienthal, H., Litens, S., Herlin, M., Hakansson, H., Canton, R. F., van den Berg, M., Visser, T. J., van Loveren, H., Vos, J. G., \& Piersma, A. H. (2009). Endocrine effects of hexabromocyclododecane 
(HBCD) in a one-generation reproduction study in Wistar rats. Toxicology Letters, 185(1), 51-6.

Wang, Z., Ciabattoni, G., Creminon, C., Lawson, J., Fitzgerald, G. A., Patrono, C., \& Maclouf, J. (1995). Immunological characterization of urinary 8-epi-prostaglandin F2 alpha excretion in man. Journal Of Pharmacology And Experimental Therapeutics, 275(1), 94-100.

Wang, W., \& Chan, J. Y. (2006). Nrfl is targeted to the endoplasmic reticulum membrane by an N-terminal transmembrane domain. Journal Of Biological Chemistry, 281, 19676-19687.

Wu, D. C., Teismann, P., Tieu, K., Vila, M., Jackson-Lewis, V., Ischiropoulos, H., \& Przedborski, S. (2003). NADPH oxidase mediates oxidative stress in the 1-methyl-4phenyl-1, 2, 3, 6-tetrahydropyridine model of Parkinson's disease. Proceedings Of The National Academy Of Sciences, 100(10), 6145-6150.

Xia, M., Huang, R., Witt, K. L., Southall, N., Fostel, J., Cho, M., Jadhav, A., Smith, C. S., Inglese, J., Portier, C. J. Tice, R. R., \& Austin, C. P.(2008). Compound cytotoxicity profiling using quantitative high-throughput screening. Environmental Health Perspectives, 116(3), 284.

Zhang, Y., Crouch, D. H., Yamamoto, M., \& Hayes, J. D. (2006). Negative regulation of 
the Nrf1 transcription factor by its N-terminal domain is independent of Keap1: Nrf1, but not Nrf2, is targeted to the endoplasmic reticulum. Biochemical Journal, 399(3), 373385.

Zhang, Y., Lucocq, J. M., Yamamoto, M., \& Hayes, J. D. (2007). The NHB1 (N-terminal homology box 1) sequence in transcription factor Nrfl is required to anchor it to the endoplasmic reticulum and also to enable its asparagine-glycosylation. Biochemical Journal, 408, 161-172.

Zhang, Y., Lucocq, J. M., \& Hayes, J. D. (2009). The Nrf1 CNC/ bZIP protein is a nuclear envelope-bound transcription factor that is activated by t-butyl hydroquinone but not by endoplasmic reticulum stressors. Biochemical Journal, 418, 293-310. 